\title{
Capability of the SMHI-RCA4 RCM driven by the ERA-Interim reanalysis to simulate heat waves in Argentina
}

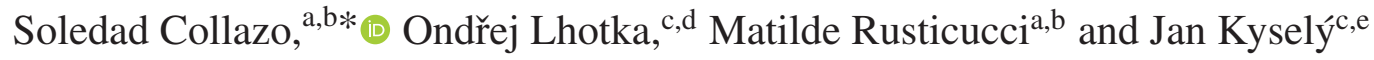 \\ ${ }^{a}$ Departamento de Ciencias de la Atmósfera y los Océanos, Facultad de Ciencias Exactas y Naturales (DCAO-FCEN-UBA), Universidad de \\ Buenos Aires, Argentina \\ b Consejo Nacional de Investigaciones Científicas y Técnicas (CONICET), Buenos Aires, Argentina \\ c Institute of Atmospheric Physics, Czech Academy of Sciences, Prague, Czech Republic \\ ${ }^{\mathrm{d}}$ Global Change Research Institute, Czech Academy of Sciences, Brno, Czech Republic \\ e Faculty of Environmental Sciences, Czech University of Life Sciences, Prague, Czech Republic
}

\begin{abstract}
The aim of the work was to evaluate the capability of the SMHI-RCA4 regional climate model (RCM) driven by the ERA-Interim reanalysis to simulate heat waves in Argentina. Firstly, we evaluated simulations of summer daily maximum temperature (Tmax) against observed data from nine stations. The model showed a warm Tmax bias at six locations and the smallest and/or negative biases were located over regions with complex topography. Heat waves were defined based on exceedances of the daily 90th percentile of Tmax at individual stations. The model overestimated the intensity, duration, and number of heat waves at all locations, but more intense heat waves were underestimated. In particular, we analysed the extreme heat wave that occurred in November 1985 in northeastern Argentina and found out that a possible reason for its underestimation was an inaccurate simulation of the sea level pressure gradient in the region. The weaker pressure gradient in the model caused a reduction of the warm northerly advection. Finally, we studied how the parameters of heat waves varied among different phases of El Niño-Southern Oscillation (ENSO) for observed and modelled data. At five stations, the strongest heat waves occurred during La Niña years and were probably associated with the decrease in precipitation.
\end{abstract}

KEY WORDS heat waves; RCM; maximum temperature; ENSO; Argentina; extreme events

Received 1 March 2017; Revised 4 May 2017; Accepted 2 June 2017

\section{Introduction}

Heat waves are associated with significant societal and economic impacts that include enhanced mortality (Robine et al., 2008; Anderson and Bell, 2009; Barriopedro et al., 2011; Pearce et al., 2016), crop failures, forest fires, stress for livestock and wildlife, spreading of pests and increased energy demand (De Bono et al., 2004; Beniston et al., 2007). It is important to assess capability of models to represent heat waves due to their aforementioned impacts. Especially, the ability to predict these extreme events would allow undertaking precautionary measures to avoid or reduce those impacts (Mueller and Seneviratne, 2012). In addition, South America is considered as a climate-data-sparse region (Menéndez et al., 2010; Tencer et al., 2011; Rusticucci, 2012; Skansi et al., 2013) and thus this study extends knowledge of heat wave characteristics in this region.

The occurrence of heat waves over subtropical South America is primarily related to the activity of synoptic-scale waves, but it is also associated with

\footnotetext{
* Correspondence to: S. Collazo, Departamento de Ciencias de la Atmósfera y los Océanos, Facultad de Ciencias Exactas y Naturales, Universidad de Buenos Aires, Intendente Güiraldes 2160, Ciudad Universitaria Pab II, 1428 Buenos Aires, Argentina. E-mail: scollazo@at.fcen.uba.ar
}

intraseasonal variability. The influence of synoptic-scale waves was analysed, e.g. by Rusticucci and Vargas (1995), Campetella and Rusticucci (1998), and Alessandro and de Garín (2003). They showed that during heat wave events, northerly winds (which contribute to temperature increase to extreme values mainly through advective processes) are present over the eastern parts of Argentina and Paraguay, southern Brazil and Uruguay. The northern flow occurs in relation with a cold front coming from the south, and a low-pressure centre in the middle of Argentina (between two high-pressure systems, Rusticucci and Vargas, 1995).

The influence of the intraseasonal variability for heat wave's development over subtropical South America during the austral summer was analysed by Cerne and Vera (2011). They found that intraseasonal variability can explain at least $32 \%$ of summer temperature variance on average and concluded that $73 \%$ of the heat waves in subtropical South America developed in association with an active South Atlantic Convergence Zone (SACZ). More recently, Alvarez et al. (2016) showed that during the austral summer (DJF), warm anomalies over the extratropical part of South America are present from phase 6 to 1 of the Madden-Julian Oscillation, when anomalous downward motion is favoured over the southeastern South America (SESA) region and anomalous upward motion is present over the SACZ region. 
Another variability mode that could modulate the intensity and persistence of heat waves in South America is El Niño-Southern Oscillation (ENSO). ENSO is the main mode of climate variability in the tropical Pacific, responsible for most interannual variability in this region and affecting the climate all over the world. During El Niño years, a cyclonic anomaly located at the southern tip of South America and an anticyclonic anomaly on the eastern coast are observed, both favouring enhanced precipitation over SESA (Grimm et al., 2000). It was also shown that the impact of El Niño on rainfall is much weaker in summer than in spring. Rusticucci et al., 2017 demonstrated that the impact of the El Niño event on extreme temperatures in Argentina had monthly differences, favouring a warming during winter (more warm nights and days) and cooler conditions in summer (less warm days and more cold days). The opposite pattern occurred during La Niña: in summer, almost all months exhibited more (less) frequent warm days (cold days) compared to their climatology.

A local process that might favour the occurrence of heat waves is the soil moisture-atmosphere interaction. Soil moisture significantly affects climate in specific regions called "hot spots" of the soil-atmosphere coupling (Koster et al., 2004). In this sense, Sörensson and Menéndez (2011) identified the region near the La Plata River in SESA as one of the main hot spots of strong coupling between soil, evapotranspiration and precipitation during summer. Strong relationship between precipitation deficits and the subsequent occurrence of hot extremes was found by Mueller and Seneviratne (2012) in a large fraction of the world (such as most areas of North and South America, Europe, Australia, and parts of China). In particular, for central and northern Argentina, these authors found significant negative correlations between the number of warm days in the warmest month of the year and the standardized precipitation index for 3, 6, and 9 preceding months. Previously, it was concluded that the soil moisture-driven regime occurs after the wet season in the Humid Pampa. Soil moisture has thus a long memory, suggesting that it plays a key role in determining surface temperature after the rainy season (De Haan and Kanamitsu, 2007). Rusticucci and Penalba (2000) showed that warm summers were associated with low precipitation, especially in northeastern and central-western Argentina, south of Chile and in Paraguay, while cool summers were related to above-normal precipitation, associated with an increased frequency of cold fronts. On the intraseasonal scale, Tencer et al. (2016) found out that heavy precipitation events (probably of convective origin) are associated with the simultaneous occurrence of warm days (maximum temperature higher than the 90th percentile) or following such an event in eastern Argentina. It has to be noticed, however, that heavy precipitation events rarely occur before the occurrence of warm days.

For a credible simulation of heat waves in Argentina, models must be capable of representing those processes accurately. In particular, regional climate models (RCMs) with higher spatial resolution than global climate models (GCMs) could be a useful tool for climatological studies of heat waves. In this sense, previous studies have shown that RCMs were able to improve the driving GCM behaviour in reproducing the observed climate anomalies in South America (Menéndez et al., 2001; Nicolini et al., 2002). The reproduction of heat waves requires not only a good simulation of the right tail of the maximum temperature distribution, but also of the persistence of extremely high maximum temperature (Tmax; Lhotka and Kyselý, 2015a). However, there are few studies that analyse daily Tmax or heat waves in RCM simulations for South America, since most previous papers have focused only on the evaluation of mean monthly temperatures. Solman et al. (2013) evaluated the performance of an ensemble of RCMs in simulating the daily mean temperature in summer. They found that the largest positive bias is located over central and northeastern Argentina and a systematic underestimation of the mean temperature is present over the Andean regions. Urrutia and Vuille (2009) have also observed a similar behaviour with the PRECIS model. More recently, Solman (2016) showed that the RCM's bias in simulating the austral summer mean temperatures over the South American continent had a different spatial distribution compared to the bias in the driving ERA-Interim reanalysis, suggesting that the biases depend more on the RCM itself than the driving model. The ERA-Interim reanalysis exhibited a negative bias over the tropics, but individual RCMs simulated both positive and negative biases depending on the RCM. Although the bias over the La Plata basin (LPB) in the ERA-Interim reanalysis was very small, a systematic warm bias could be identified in every RCM (the RCA and LMDZ RCMs exhibited the smallest biases; Solman, 2016). Turning to extreme events, Carril et al. (2012) evaluated the performance of a multi-RCM ensemble when simulating maximum and minimum temperature in terms of seasonal means and extreme indices based on a percentile approach in SESA. López-Franca et al. (2016) examined a set of four extreme temperature indices from an ensemble of four RCMs for present and future periods in South America. They showed that the RCM ensemble captured the regional spatial features of the seasonal mean of minimum and maximum temperature better than any of the individual models. Nevertheless, warm biases were identified over the Amazon basin and LPB, and cold biases were found in topographically complex areas with high altitude, especially during the austral summer. In the 1990-2000 period, Tencer et al. (2016) also identified that a multimodel ensemble of RCMs overestimated the daily 90th percentile of Tmax in the central part of Argentina and underestimated it in the west and northeast during the warm season. Finally, Carril et al. (2016) showed that a multi-RCM ensemble overestimated the duration of warm spells by a rate of about $60-150 \%$ in LPB, but the geographical structure of the field was captured well.

The main objective of this article is to evaluate the performance of the SMHI-RCA4 RCM driven by ERA-Interim to simulate summer Tmax and heat waves in Argentina north of $40^{\circ} \mathrm{S}$ in the $1980-2010$ period. The intensity, duration, temporal distribution and number of heat waves were analysed for both observed and model data. 


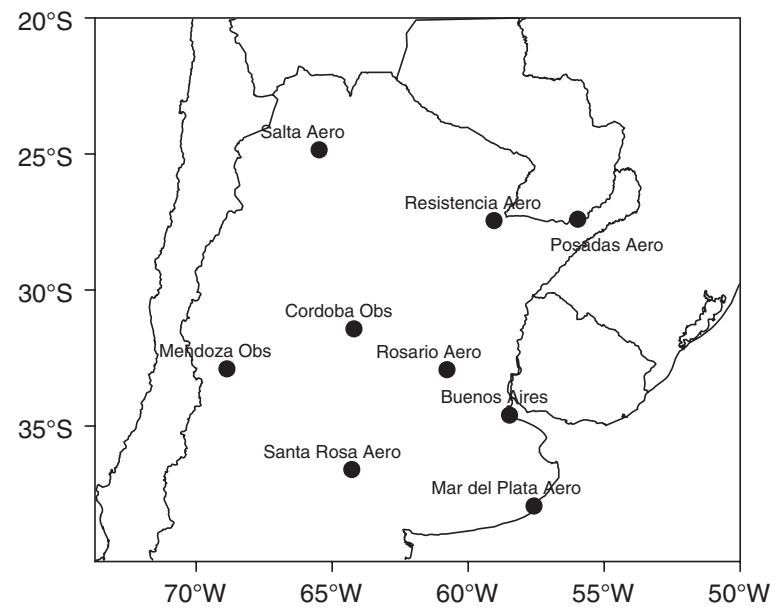

Figure 1. Locations of the nine weather stations examined in Argentina north of $40^{\circ} \mathrm{S}$.

Characteristics of a selected intense heat wave and related circulation pattern were also analysed. Finally, we explored the influence of the ENSO on heat waves by analysing changes in their parameters between different phases.

\section{Data and methodology}

\subsection{Observed data}

The data were obtained from nine stations over Argentina north of $40^{\circ} \mathrm{S}$ and distributed throughout the region (Figure 1). This is the most populated region of Argentina, and it is prone to severe heat waves. We utilized daily Tmax in the 1980-2010 period provided by the Argentine National Weather Service. A quality control analysis was performed for these stations. The stations Rosario, Mendoza, Posadas, Mar del Plata and Resistencia have missing data (less than $3 \%$ of the daily Tmax data) which were excluded from all calculations. For the November 1985 heat wave case study, we also employed daily Tmax, sea level pressure and precipitation data from National Centers for Environmental Prediction/Department of Energy (NCEP/DOE) Reanalysis-II (R2; Kanamitsu et al., 2002) with a global T62 Gaussian grid $(192 \times 94)$ and from the ERA-Interim reanalysis (Dee et al., 2011) with a spatial resolution of $0.75^{\circ} \times 0.75^{\circ}$.

\subsection{Regional climate model simulation}

We used daily Tmax, sea level pressure and precipitation data from the RCA4 RCM developed in the Swedish Meteorological and Hydrological Institute (SMHI) driven by the ERA-Interim reanalysis (more information about the RCA RCM is given in Samuelsson et al., 2011). This simulation is a part of the Coordinated Regional Downscaling Experiment (CORDEX) project and covers the 1980-2010 period. The domain is South America (SAM-44), using a rotated latitude/longitude grid with the North Pole coordinates at $70.60^{\circ} \mathrm{N}, 303.94^{\circ} \mathrm{E}$ and the $0.44^{\circ}$ resolution. The CORDEX protocol includes the definition of common domains covering the majority of land areas around the world and several general characteristics of RCM configuration, such as resolution, model domain, source of boundary conditions, and simulated periods (Solman, 2013). We chose this model because it had the longest available simulation in the region and it was one of the best models in reproducing the summer mean temperature in the 1990-2008 period (Solman, 2016).

For each station, four nearest grid points in the model were searched and then we calculated a spatial average of Tmax using the inverse distance weighting (IDW) method. Table 1 shows the real location of the stations and their respective nearest grid points in rotated coordinates and corresponding values in the latitude/longitude coordinates system. In the next step, the influence of the differences in altitude between the model and observed data on Tmax was removed by considering a gradient of $0.6^{\circ} \mathrm{C}$ per $100 \mathrm{~m}$. The most important correction was applied in Mendoza due to the complex topography.

In order to assess how the model represented the summer (DJF) maximum temperature at each station, we estimated the bias, the root-mean-square error (RMSE), the difference in the 90th percentile between the model and observed data, and the correlation coefficient (the latter statistically tested). Finally, box plots were made in order to compare the Tmax distribution between the model and the observations.

\subsection{Heat wave definition}

There are many definitions of heat waves (e.g. Cerne and Vera, 2011; Rusticucci et al., 2016), but all of them regard heat waves as periods of consecutive days when weather conditions are excessively hotter than normal (Perkins and Alexander, 2013). On the basis of this definition, a heat wave can occur anytime during the year (Lhotka and Kyselý, 2015b), but we focused on the warm season (October-March) only, because heat waves have the largest impacts on human health and the environment during this time of year (Rusticucci et al., 2016). Firstly, we calculated the daily 90th percentile of Tmax considering the complete period (1980-2010) at each station. A heat wave occurred when Tmax was above this threshold for at least 3 consecutive days, in accordance with previous studies (Meehl and Tebaldi, 2004; Della-Marta et al., 2007; Kyselý, 2010; Lhotka and Kyselý, 2015c; Rusticucci et al., 2016). This definition was applied to both simulated and observed data.

\subsection{Heat wave parameters}

In order to characterize heat waves, several parameters were used for both observed and modelled data. Analogously to Kyselý (2010), the TS90 index was defined to describe the intensity of heat waves. This index uses the sum of Tmax excesses above the 90th percentile for all heat waves in each warm season and is given in ${ }^{\circ} \mathrm{C}$. The daily 90th percentile was calculated separately for the observed data and the model simulation in order to remove the influence of the Tmax bias. We also defined hot day 
Table 1. Location and altitude of stations examined and the four nearest grid points in SMHI-RCA4 RCM used for spatial interpolation.

\begin{tabular}{|c|c|c|c|c|c|c|}
\hline & $\begin{array}{l}\text { Longitude } \\
\left({ }^{\circ} \mathrm{W}\right)\end{array}$ & $\begin{array}{l}\text { Latitude } \\
\left({ }^{\circ} \mathrm{S}\right)\end{array}$ & $\begin{array}{c}\text { Station } \\
\text { altitude }(\mathrm{m})\end{array}$ & $\begin{array}{l}\text { Rotated } \\
\text { longitude }\end{array}$ & $\begin{array}{l}\text { Rotated } \\
\text { latitude }\end{array}$ & $\begin{array}{l}\text { Model grid } \\
\text { altitude }(\mathrm{m})\end{array}$ \\
\hline \multirow[t]{4}{*}{ Buenos Aires } & 58.48 & 34.59 & 25 & $79\left(58.1^{\circ} \mathrm{W}\right)$ & $54\left(34.3^{\circ} \mathrm{S}\right)$ & 13.1 \\
\hline & & & & $78\left(58.6^{\circ} \mathrm{W}\right)$ & $54\left(34.3^{\circ} \mathrm{S}\right)$ & 9.8 \\
\hline & & & & $78\left(58.6^{\circ} \mathrm{W}\right)$ & $53\left(34.8^{\circ} \mathrm{S}\right)$ & 19.6 \\
\hline & & & & $79\left(58.1^{\circ} \mathrm{W}\right)$ & $53\left(34.8^{\circ} \mathrm{S}\right)$ & 11.4 \\
\hline \multirow[t]{4}{*}{ Cordoba Obs } & 64.18 & 31.40 & 425 & $67\left(64,1^{\circ} \mathrm{W}\right)$ & $61\left(31.1^{\circ} \mathrm{S}\right)$ & 546.6 \\
\hline & & & & $66\left(64.6^{\circ} \mathrm{W}\right)$ & $61\left(31.1^{\circ} \mathrm{S}\right)$ & 1054.0 \\
\hline & & & & $66\left(64.6^{\circ} \mathrm{W}\right)$ & $60\left(31.5^{\circ} \mathrm{S}\right)$ & 1178.0 \\
\hline & & & & $67\left(64,1^{\circ} \mathrm{W}\right)$ & $60\left(31.6^{\circ} \mathrm{S}\right)$ & 484.6 \\
\hline \multirow[t]{4}{*}{ Rosario Aero } & 60.78 & 32.92 & 25 & $74\left(60.6^{\circ} \mathrm{W}\right)$ & $58\left(32.5^{\circ} \mathrm{S}\right)$ & 24.5 \\
\hline & & & & $73\left(61.1^{\circ} \mathrm{W}\right)$ & $58\left(32.5^{\circ} \mathrm{S}\right)$ & 39.2 \\
\hline & & & & $73\left(61.2^{\circ} \mathrm{W}\right)$ & $57\left(33.0^{\circ} \mathrm{S}\right)$ & 57.1 \\
\hline & & & & $74\left(60.6^{\circ} \mathrm{W}\right)$ & $57\left(33.0^{\circ} \mathrm{S}\right)$ & 22.8 \\
\hline \multirow[t]{4}{*}{ Mendoza Obs } & 68.87 & 32.89 & 827 & $58\left(68.8^{\circ} \mathrm{W}\right)$ & $56\left(33.1^{\circ} \mathrm{S}\right)$ & 1067.0 \\
\hline & & & & $57\left(69.3^{\circ} \mathrm{W}\right)$ & $56\left(33.0^{\circ} \mathrm{S}\right)$ & 2656.2 \\
\hline & & & & $57\left(69.3^{\circ} \mathrm{W}\right)$ & $57\left(32.6^{\circ} \mathrm{S}\right)$ & 2530.5 \\
\hline & & & & $58\left(68.8^{\circ} \mathrm{W}\right)$ & $57\left(32.6^{\circ} \mathrm{S}\right)$ & 1042.6 \\
\hline \multirow[t]{4}{*}{ Posadas Aero } & 55.97 & 27.39 & 125 & $83\left(56.1^{\circ} \mathrm{W}\right)$ & $70\left(27.3^{\circ} \mathrm{S}\right)$ & 102.8 \\
\hline & & & & $84\left(55.6^{\circ} \mathrm{W}\right)$ & $70\left(27.3^{\circ} \mathrm{S}\right)$ & 156.6 \\
\hline & & & & $84\left(55.6^{\circ} \mathrm{W}\right)$ & $69\left(27.8^{\circ} \mathrm{S}\right)$ & 156.6 \\
\hline & & & & $83\left(56.1^{\circ} \mathrm{W}\right)$ & $69\left(27.8^{\circ} \mathrm{S}\right)$ & 107.7 \\
\hline \multirow[t]{4}{*}{ Mar del Plata Aero } & 57.58 & 37.93 & 21 & $80\left(57.6^{\circ} \mathrm{W}\right)$ & $46\left(37.9^{\circ} \mathrm{S}\right)$ & 35.9 \\
\hline & & & & $81\left(57.1^{\circ} \mathrm{W}\right)$ & $46\left(37.9^{\circ} \mathrm{S}\right)$ & 3.3 \\
\hline & & & & $81\left(57.1^{\circ} \mathrm{W}\right)$ & $45\left(38.3^{\circ} \mathrm{S}\right)$ & 0.0 \\
\hline & & & & $80\left(57.7^{\circ} \mathrm{W}\right)$ & $45\left(38.3^{\circ} \mathrm{S}\right)$ & 11.4 \\
\hline \multirow[t]{4}{*}{ Resistencia Aero } & 59.05 & 27.44 & 52 & $77\left(59.0^{\circ} \mathrm{W}\right)$ & $70\left(27.3^{\circ} \mathrm{S}\right)$ & 52.0 \\
\hline & & & & $77\left(59.0^{\circ} \mathrm{W}\right)$ & $69\left(27.7^{\circ} \mathrm{S}\right)$ & 47.3 \\
\hline & & & & $76\left(59.5^{\circ} \mathrm{W}\right)$ & $69\left(27.7^{\circ} \mathrm{S}\right)$ & 58.7 \\
\hline & & & & $76\left(59.5^{\circ} \mathrm{W}\right)$ & $70\left(27.3^{\circ} \mathrm{S}\right)$ & 62.0 \\
\hline \multirow[t]{4}{*}{ Salta Aero } & 65.48 & 24.84 & 1221 & $64\left(65.2^{\circ} \mathrm{W}\right)$ & $75\left(24.9^{\circ} \mathrm{S}\right)$ & 1262.8 \\
\hline & & & & $63\left(65.7^{\circ} \mathrm{W}\right)$ & $75\left(24.9^{\circ} \mathrm{S}\right)$ & 2636.6 \\
\hline & & & & $63\left(65.7^{\circ} \mathrm{W}\right)$ & $76\left(24.4^{\circ} \mathrm{S}\right)$ & 3259.8 \\
\hline & & & & $64\left(65.2^{\circ} \mathrm{W}\right)$ & $76\left(24.5^{\circ} \mathrm{S}\right)$ & 1326.5 \\
\hline \multirow[t]{4}{*}{ Santa Rosa Aero } & 64.28 & 36.59 & 191 & $67\left(64.4^{\circ} \mathrm{W}\right)$ & $49\left(36.4^{\circ} \mathrm{S}\right)$ & 181.1 \\
\hline & & & & $68\left(63.9^{\circ} \mathrm{W}\right)$ & $49\left(36.4^{\circ} \mathrm{S}\right)$ & 138.7 \\
\hline & & & & $68\left(63.9^{\circ} \mathrm{W}\right)$ & $48\left(36.8^{\circ} \mathrm{S}\right)$ & 137.1 \\
\hline & & & & $67\left(64.4^{\circ} \mathrm{W}\right)$ & $48\left(36.8^{\circ} \mathrm{S}\right)$ & 190.9 \\
\hline
\end{tabular}

as a day when Tmax exceeded the daily 90th percentile. Other parameters estimated were the total duration of heat waves in the warm season (i.e. the number of days with heat waves in a season), the number of heat waves by warm season and the mean duration of a heat wave. In addition, we accumulated all parameters throughout the entire period during the different phases of the ENSO. Finally, we determined the frequency of heat waves during the warm season and their 31-day moving average in order to analyse their temporal occurrence.

In order to classify warm seasons according to the ENSO events, we considered the Oceanic Niño Index (ONI) obtained from the National Oceanic and Atmospheric Administration (NOAA) website. The ONI is based on the NOAA ERSST v.4 sea surface temperature anomalies in the Niño 3.4 region $\left(5^{\circ} \mathrm{N}-5^{\circ} \mathrm{S}, 120^{\circ} \mathrm{W}-170^{\circ} \mathrm{W}\right)$, taking $1986-2015$ as the base period. According to the historical standards for classification of El Niño or La Niña events, the $\pm 0.5^{\circ} \mathrm{C}$ threshold must be surpassed for at least 5 consecutive months when the 3-month running mean of ERSST.v4 is considered. This definition was chosen because it is the standard index that NOAA uses for identifying El Niño and La Niña events in the tropical Pacific.

\section{Results}

3.1. Evaluation of summer maximum temperature in the SMHI-RCA4 model

In order to evaluate the capability of the SMHI-RCA4 model to simulate Tmax, we calculated the bias and RMSE of daily Tmax in summer, difference in the 90th percentile of daily Tmax, and correlation coefficient between daily Tmax in the observed data and SMHI-RCA4 (Table 2). Six of the nine locations analysed had a warm bias indicating an overestimation of the summer Tmax by the model, with the greatest bias at the Rosario station located in LPB (almost $4.5^{\circ} \mathrm{C}$ ). Small negative biases were found in the western locations (Mendoza and Salta) and in the northeast in Posadas. Salta and Posadas had almost no bias, but the RMSE was similar to other stations, indicating that 
Table 2. Correlation coefficient, bias and RMSE between observed and modelled daily summer Tmax, and difference in the 90th percentile of daily summer maximum temperature between the modelled and observed data in the 1980-2010 period.

\begin{tabular}{lcrrr}
\hline & Correlation & $\begin{array}{r}\mathrm{BIAS} \\
\left({ }^{\circ} \mathrm{C}\right)\end{array}$ & $\begin{array}{c}\text { RMSE } \\
\left({ }^{\circ} \mathrm{C}\right)\end{array}$ & $\begin{array}{c}\text { P90mod- } \\
\text { P90obs } \\
\left({ }^{\circ} \mathrm{C}\right)\end{array}$ \\
\hline Buenos Aires & $\mathbf{0 . 6 4 *}$ & 2.45 & 4.22 & 3.68 \\
Cordoba Obs & $\mathbf{0 . 5 9 *}$ & 0.94 & 3.43 & 0.81 \\
Rosario Aero & $\mathbf{0 . 5 9 *}$ & 4.35 & 5.54 & 4.91 \\
Mendoza Obs & $\mathbf{0 . 6 7 *}$ & -0.74 & 2.81 & -0.94 \\
Posadas Aero & $\mathbf{0 . 3 9 *}$ & -0.10 & 3.82 & 0.92 \\
Mar del Plata Aero & $\mathbf{0 . 7 2 *}$ & 0.18 & 3.29 & -0.48 \\
Resistencia Aero & $\mathbf{0 . 4 3 *}$ & 2.24 & 4.42 & 2.29 \\
Salta Aero & $\mathbf{0 . 5 9 *}$ & -0.04 & 2.92 & -0.60 \\
Santa Rosa Aero & $\mathbf{0 . 7 0 *}$ & 1.62 & 3.66 & 1.77 \\
\hline
\end{tabular}

Correlation coefficients in bold are significant at $5 \%$.

there was a compensation of the model errors (Figure S1, Supporting information). The correlations between the daily Tmax in the model and in the observations were statistically significant at all locations analysed. In addition, the model representation of the tail of the Tmax distribution was studied by comparing the 90th percentile with observations. This analysis was important because we analysed the capability of SMHI-RCA4 to simulate heat waves that are associated with such high temperatures. Analogously to the Tmax bias, an overestimation of the 90th percentile was found at six locations while an underestimation of the 90th percentile was observed in the western stations and also in the south-east (Mar del Plata).

Figure 2 shows the difference in the Tmax distributions between the SMHI-RCA4 RCM and observations through boxplots for each location. In Posadas and Mar del Plata, the largest difference between modelled and observed Tmax distributions was in the interquartile range (IQR): in Posadas, the modelled data had wider IQR compared to observed data, while in Mar del Plata an opposite behaviour was found. In Salta, the range of Tmax was underestimated by the SMHI-RCA4 RCM. The modelled (a)

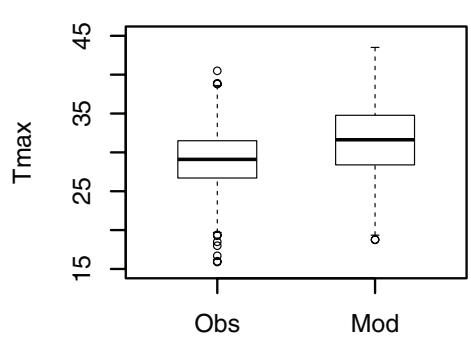

(d)

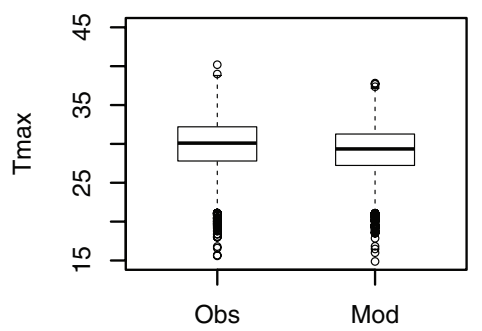

(g)

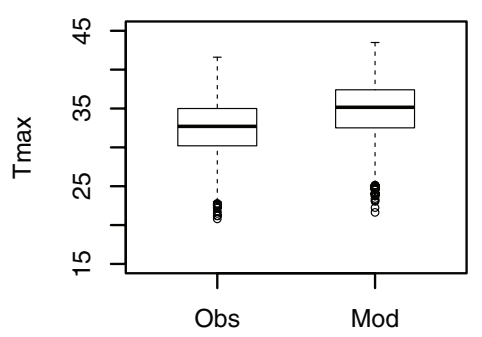

(b)

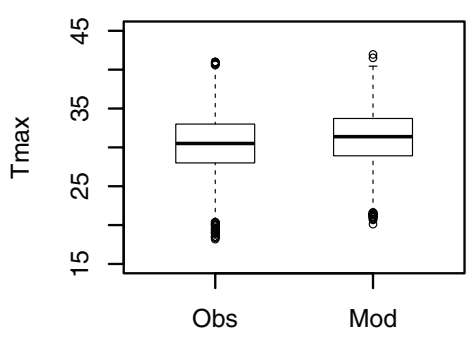

(e)

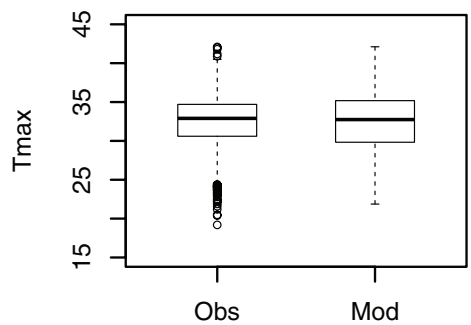

(h)

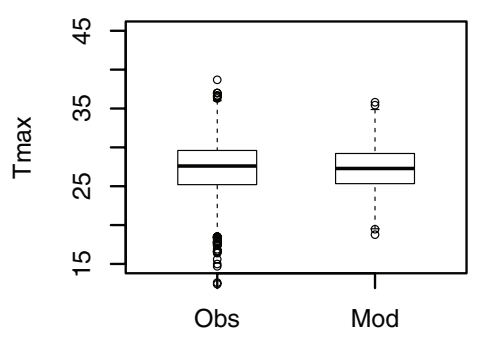

(c)

Rosario Aero

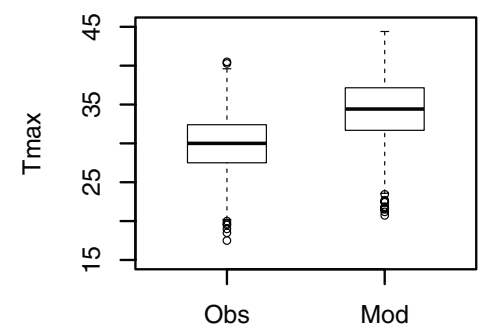

(f)

Mar del Plata Aero

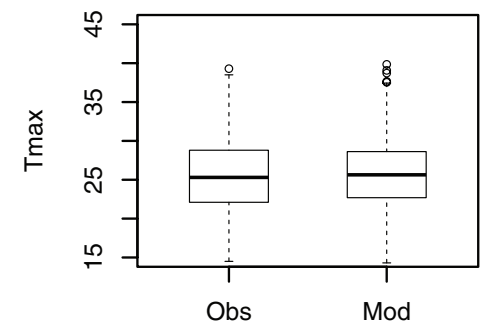

(i)

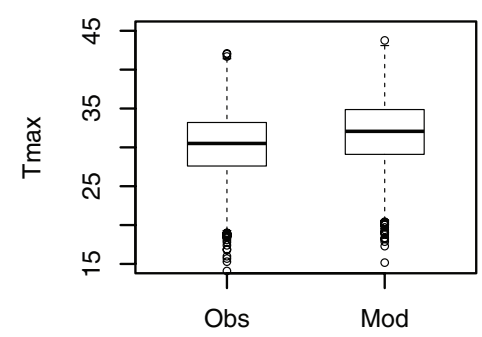

Figure 2. Box plots comparing the summer Tmax $\left({ }^{\circ} \mathrm{C}\right)$ distribution of the observed and modelled data in the $1980-2010$ period. The modelled data were interpolated using an average of Tmax over the four nearest grid points. Boxes represent the interquartile range (i.e. the range between the 25 th and 75th percentiles) and black solid line within the boxes is the median. The whiskers extend up to 1.5 times the interquartile range from the top (bottom) of the box to the furthest data within that distance. If there are any data beyond that distance ('outliers'), they are represented individually as points. 
(a)

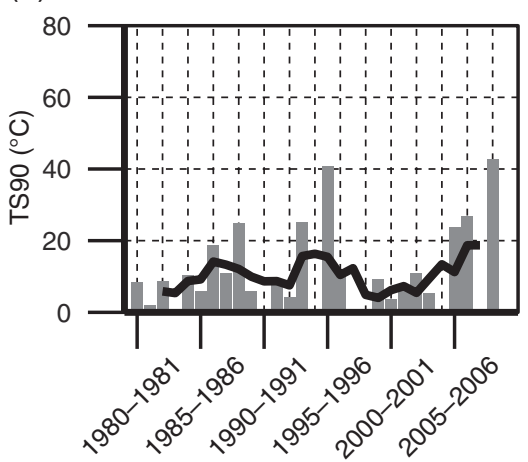

(d)

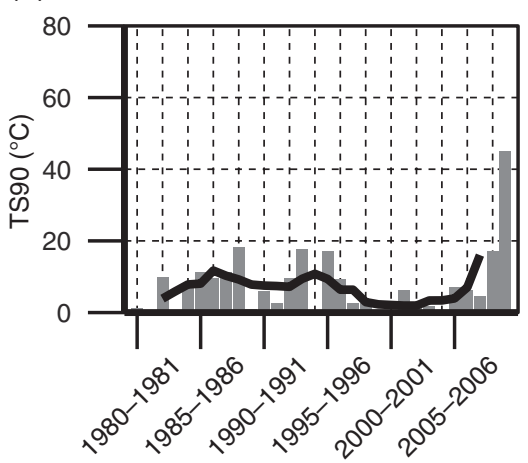

(g)

Resistencia Aero

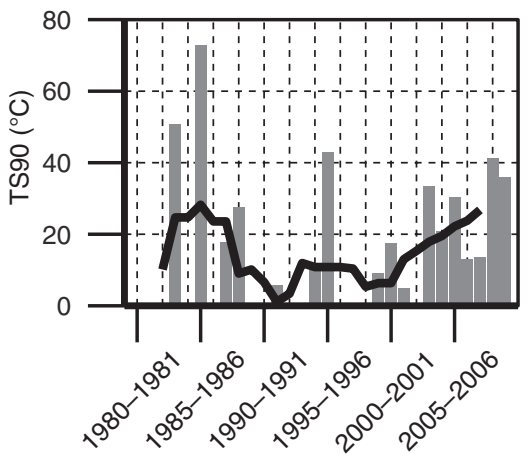

(b)

Cordoba Obs

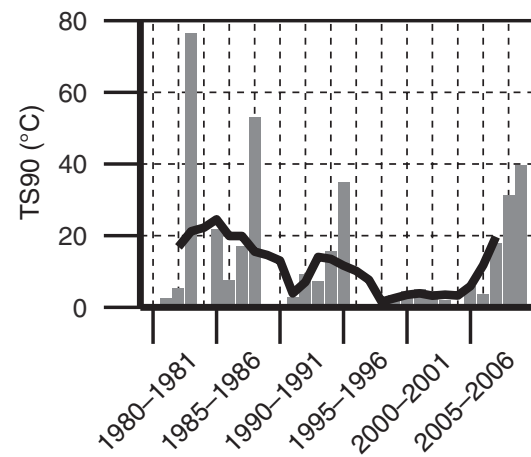

(e)
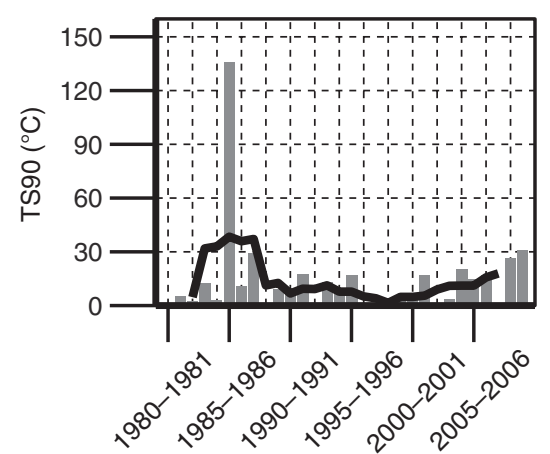

(h)

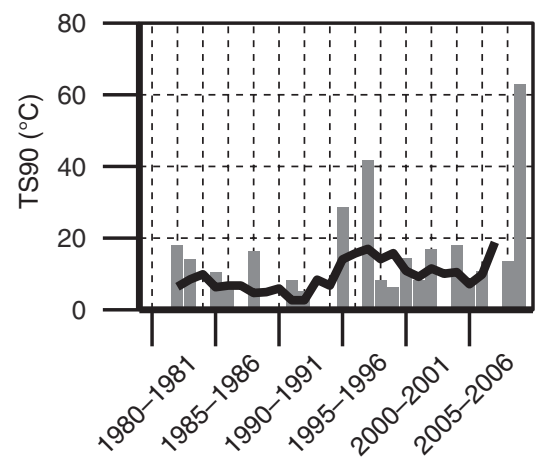

(c) Rosario Aero

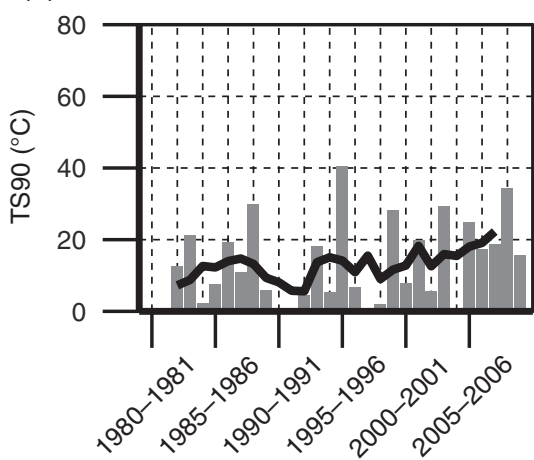

(f) Mar del Plata Aero

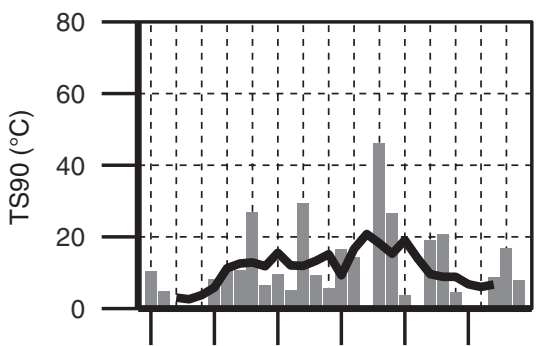

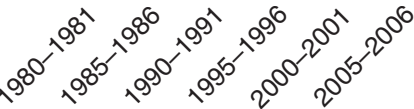

(i) Santa Rosa Aero

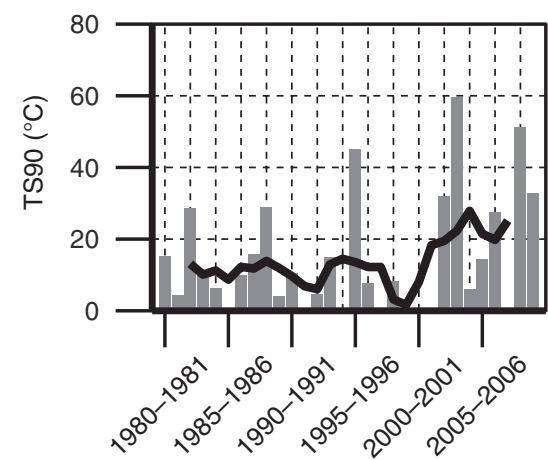

Figure 3. Seasonal sum of positive daily $T$ max excesses above the daily 90 th percentile for all heat waves (TS90 index, ${ }^{\circ} \mathrm{C}$ ) for observed data (1980-2010). The line represents the five-warm seasons moving average.

Tmax was underestimated uniformly across the Tmax distribution in Mendoza, while an overestimation was found in other locations.

\subsection{Evaluation of heat wave characteristics in the SMHI-RCA4 model}

We calculated the TS90 index for observations at each station (Figure 3) and then analysed the difference in the TS90 index between the model and observations (Figure 4). In the central region (Buenos Aires, Cordoba and Rosario), the seasonal TS90 index was most pronounced in the 1995-1996 and 2008-2009 warm seasons (Figures 3(a)-(c)) in the observed data. In addition, Cordoba exhibited the largest values of the TS90 index in the 1983-1984 and 1988-1989 warm seasons. The RCA4 model was able to reproduce the TS90 index during the 1995-1996 and 2008-2009 warm seasons quite well in Rosario but an underestimation was found in Buenos Aires. In Cordoba, the most extreme warm season 1983-1984 was considerably underestimated by the model (Figures 4(a)-(c)). In Buenos Aires and Rosario, the most severe observed heat wave occurred in the 1995-1996 warm season: from November 1 to November 6 in Buenos Aires and from December 16 to December 20 in Rosario. During the Buenos Aires heat wave, the model did not simulate a heat wave but it was able to represent 3 hot days on November 2, 3 and 6 at least. In Rosario, the model simulated a heat wave that was weaker. In Cordoba, the most severe heat wave occurred between 2 October and 7 October 1983 and its severity was considerably underestimated by the model. 

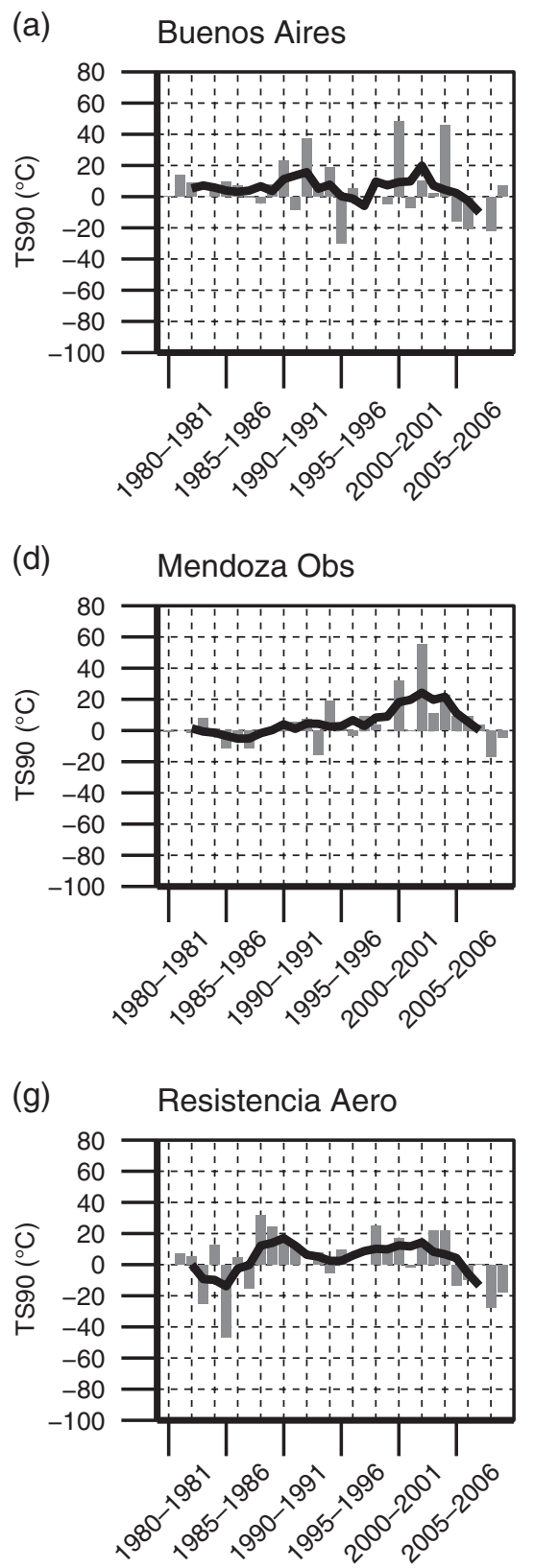

(b)

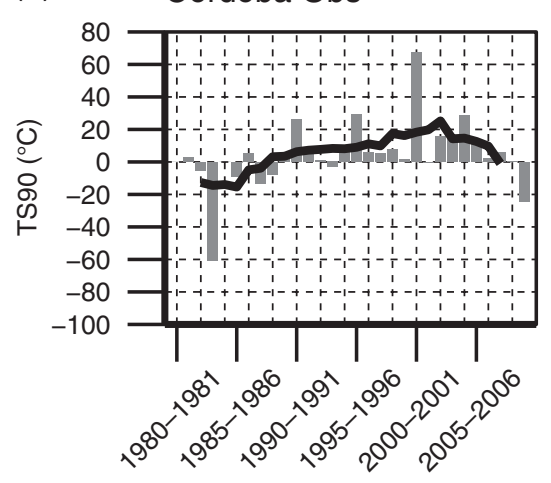

(e)

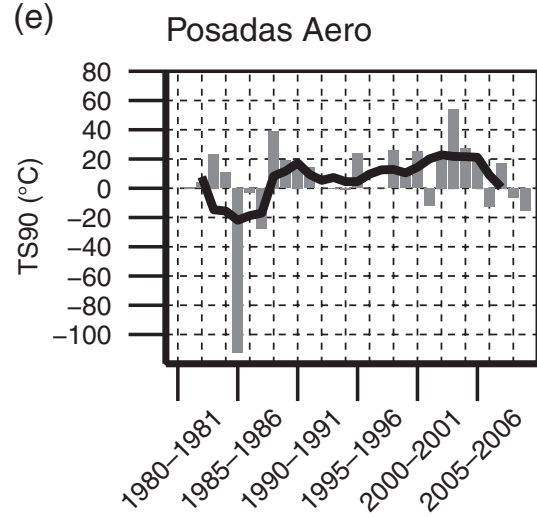

(h)

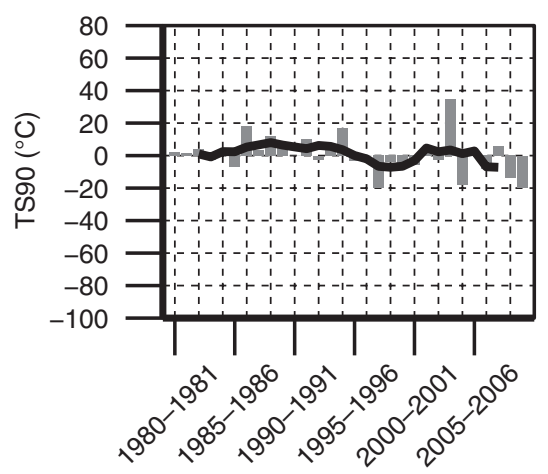

(c)

Rosario Aero

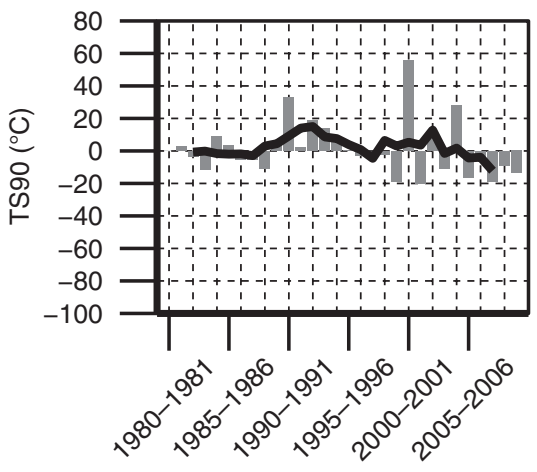

(f)

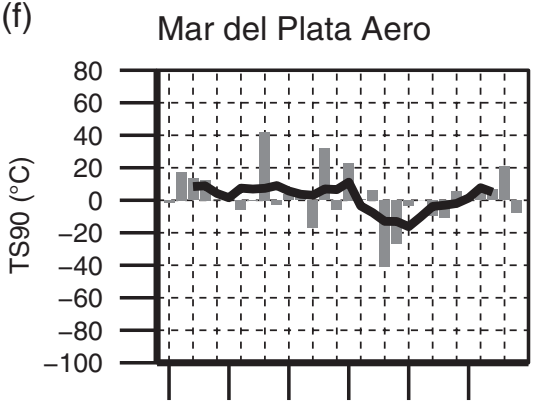

(i)

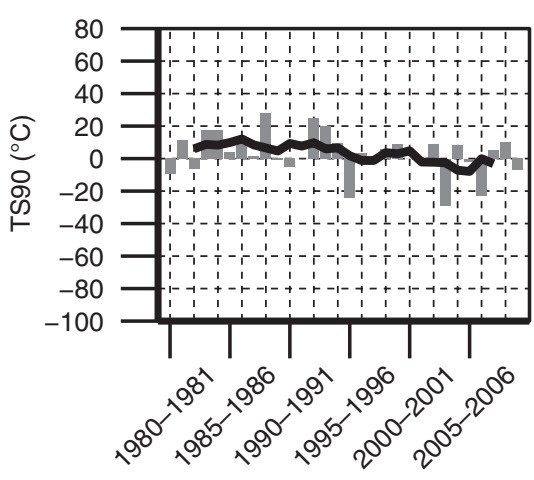

Figure 4. Difference between model and observations in the seasonal sum of positive daily Tmax excesses above the daily 90 th percentile for all heat waves (TS90 index, ${ }^{\circ} \mathrm{C}$ ) for each warm season in the 1980-2010 period. The line represents the five-warm seasons moving average.

In northeastern Argentina, Posadas and Resistencia had the maximum value of the TS90 index in the 1985-1986 warm season (Figures 3(e) and (g)). Although this warm season is the only one with a high value of TS90 in Posadas, other intense warm seasons such as 1983-1984 and 1995-1996 occurred in Resistencia. In both locations, the model underestimated the TS90 index in the 1985-1986 warm season (Figures 4(e) and (g)). In this season, Posadas exhibited the highest value of TS90 $\left(136.1^{\circ} \mathrm{C}\right)$ among all stations. This extreme value was the result of the occurrence of 9 heat waves in a single season (Figure S3). The model substantially underestimated the seasonal TS90 index (the difference between the observed and simulated TS90 index was higher than $100^{\circ} \mathrm{C}$ ) for this warm season (Figure 4(e)). The most severe heat wave observed at Posadas took place between 9 November and 19 November in 1985 , when the TS90 index was $56.0^{\circ} \mathrm{C}$. The model only reproduced 3 hot days in this period (on November 13, 14 and 16). This particular heat wave is analysed in more detail in Section 3.3. At Resistencia, the second most intense heat wave occurred in November 1985 and it was also underestimated. By contrast, the most intense heat wave occurred from 3 November to 8 November in 1995 (TS90 index $=28.7^{\circ} \mathrm{C}$ ), and it was quite well simulated by the model $\left(\right.$ TS90 index $\left.=25.7^{\circ} \mathrm{C}\right)$.

In the western region (Mendoza and Salta), the highest value of the TS90 index was observed in the 2009-2010 warm season (Figures 3(d) and (h)). Heat waves were more intense in Salta compared to Mendoza, mainly since 1995. The most severe heat wave in Mendoza occurred between 
Table 3. Comparison of the heat waves parameters accumulated in the 1980 - 2010 period between observations and the SMHI-RCA4 model.

\begin{tabular}{|c|c|c|c|c|c|c|c|c|}
\hline \multirow[t]{2}{*}{ Station } & \multicolumn{4}{|c|}{ Observation (1980-1981 to 2009-2010) } & \multicolumn{4}{|c|}{ SMHI RCA4 } \\
\hline & HD & HW & Duration (days) & $\mathrm{TS} 90\left({ }^{\circ} \mathrm{C}\right)$ & $\mathrm{HD}$ & HW & Duration (days) & $\mathrm{TS} 90\left({ }^{\circ} \mathrm{C}\right)$ \\
\hline Buenos Aires & 534 & 42 & 155 & 316 & 547 & 53 & 210 & 459 \\
\hline Cordoba Obs & 534 & 43 & 157 & 372 & 547 & 57 & 257 & 499 \\
\hline Rosario Aero & 537 & 53 & 195 & 390 & 546 & 59 & 239 & 427 \\
\hline Mendoza Obs & 532 & 39 & 133 & 229 & 547 & 55 & 229 & 368 \\
\hline Posadas Aero & 535 & 56 & 228 & 410 & 546 & 65 & 294 & 570 \\
\hline Mar del Plata Aero & 535 & 41 & 136 & 323 & 546 & 38 & 137 & 383 \\
\hline Resistencia Aero & 535 & 49 & 210 & 448 & 546 & 65 & 287 & 527 \\
\hline Salta Aero & 530 & 46 & 161 & 316 & 546 & 55 & 214 & 328 \\
\hline Santa Rosa Aero & 537 & 54 & 196 & 439 & 547 & 57 & 235 & 527 \\
\hline
\end{tabular}

October 27 and October 31 in the 2009-2010 warm season and it was well represented by the model. Salta had the most severe heat wave between October 28 and November 22009 and it was underestimated by the SMHI-RCA4 RCM. In general, the model overestimated the TS90 index in Mendoza mainly in the last decade (Figure 4(d)).

Different patterns were observed at southern stations, Mar del Plata and Santa Rosa. Santa Rosa exhibited high values of the TS90 index in several warm seasons, especially since 1995-1996, while Mar del Plata registered less variability and it showed a maximum of the TS90 index in the 1998-1999 warm season (Figures 3(f) and (i)). The model errors in Mar del Plata were larger than in Santa Rosa, probably due to the difficulty of modelling the sea-land interaction (Figures 4(f) and (i)). The most intense heat wave in Mar del Plata occurred between 24 December and 27 December 1998, while in Santa Rosa the most intense heat wave was observed from 2 December to 6 December 1995. In both cases, the model simulated only 2 hot days.

To sum up, Table 3 shows the heat wave parameters accumulated in the complete 1980-2010 period. The number of heat waves and their total duration were considerably larger in modelled data, which is linked to overestimated sums of the TS90 index at all locations. In addition, the observed TS90 index, number of heat waves and days with heat waves in a warm season did not present significant trends at the $5 \%$ confidence level at any of the stations.

Another measure to evaluate the performance of the model is the comparison of the frequency of heat wave days during the warm season between the observations and SMHI-RCA4 (Figure 5). In many of the stations analysed, the model overestimated the frequency of heat waves, especially from December to the end of the warm season. Only in Mar del Plata and Santa Rosa, the model underestimated the frequency of heat waves in December and January, while an overestimation was observed in February and March (Figures 5(f) and (i)).

\subsection{November 1985 heat wave in Posadas}

The most severe heat wave in Posadas that occurred from 9 November to 19 November 1985 (cf. Section 3.2) was analysed in more detail. The model considerably underestimated this heat wave. Figure 6 presents the observed and simulated daily Tmax at the Posadas station during this heat wave. The model underestimated Tmax on all days, in particular since November 17 when the model simulated a marked drop in Tmax, while the observed Tmax was still higher than $40^{\circ} \mathrm{C}$. Possible reasons for this underestimation may be related to an erroneous reproduction of mean sea level pressure and preceding precipitation (Figure 7). Comparing SMHI-RCA4 with the R2, we found higher anomalies of Tmax in northeastern Argentina and southern Brazil (between $20-30^{\circ} \mathrm{S}$ and $50-63^{\circ} \mathrm{W}$ ) in the reanalysis data. Even the ERA-Interim reanalysis, which was used as a driving data for SMHI-RCA RCM, showed higher Tmax anomalies in the region. This difference is due to the fact that the ERA-Interim and R2 reanalyses had a larger anticyclonic anomaly and a sea level pressure gradient in the region that favours an increased northerly advection which is responsible for the rise of Tmax. Another difference between SMHI-RCA4 and the reanalysis could be seen in the field of precipitation anomalies in the previous month: R2 shows drier conditions than SMHI-RCA4 in northeastern Argentina. ERA-Interim also exhibited negative (although less pronounced) anomalies of precipitation near Posadas. Drier soils favoured an increase of sensible heat flux and warmer conditions (Seneviratne et al., 2011). In addition, comparing the observed $(44.5 \mathrm{~mm})$ and modelled $(71.4 \mathrm{~mm}) \mathrm{accu}-$ mulated precipitation in October 1985 at Posadas shows an overestimation in the model. Nevertheless, both values are below the October climatology for Posadas (the climatological value in the 1981-2010 period was $226 \mathrm{~mm}$ for the observed data and $76.5 \mathrm{~mm}$ for the modelled data). The large difference between the climatological values indicates that the model has difficulties in representing precipitation in this region. These differences in the circulation patterns and precipitation rates might be responsible for the underestimation of the heat wave by the model. In order to obtain more robust results, we compared mean sea level pressure and preceding precipitation with other reanalyses (National Centers for Envioronmental Prediction/National Center for Atmospheric Research (NCEP/NCAR) Reanalysis I and Japanese 55-year Reanalysis (JRA-55)) and found similar patterns (Figures S6 and S7). 
(a)

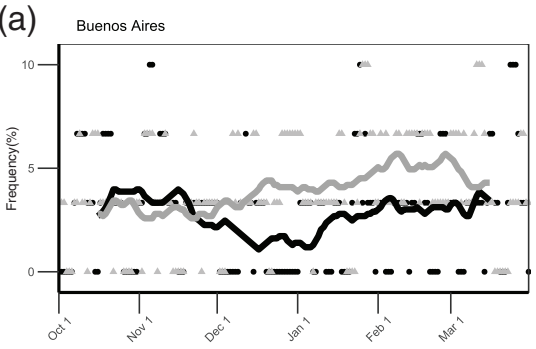

(d)

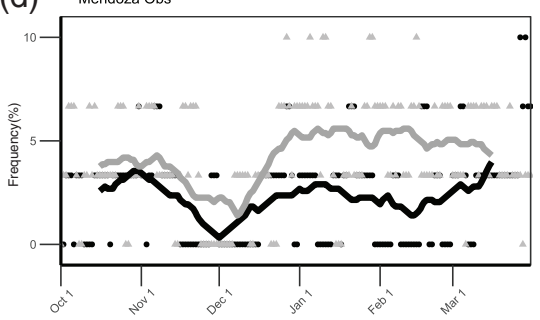

(g)

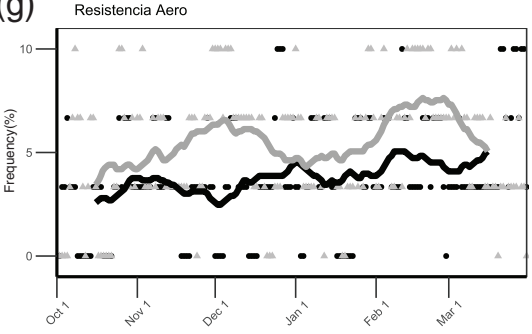

(b) Cordoba obs

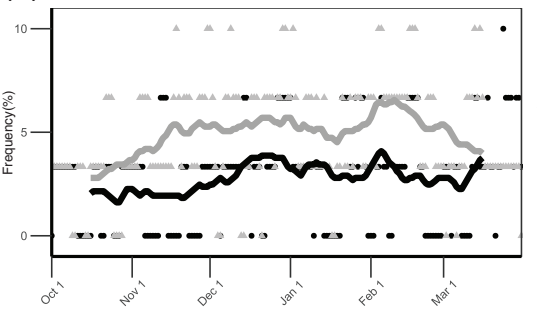

(e) Posadas Aero

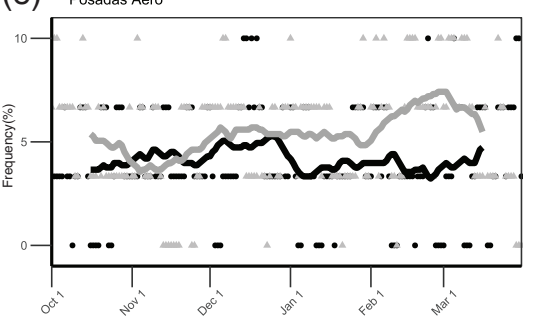

(h)

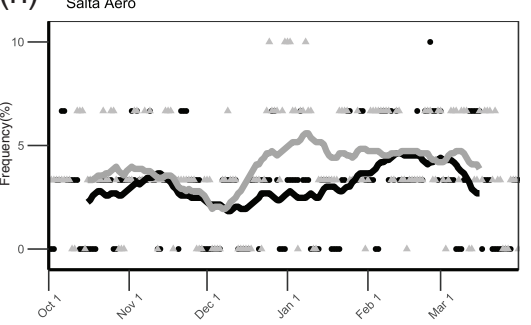

(c) Rosario Aero

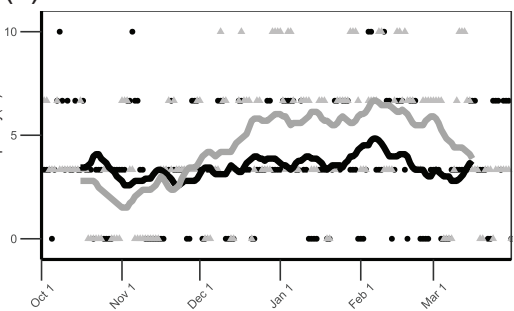

(f) Mard del PLata Aero

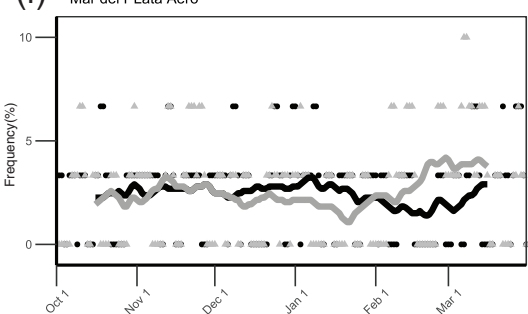

(i) Santa Rosa Aero

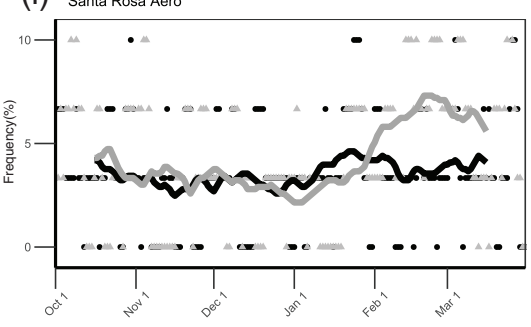

Figure 5. Daily frequency of heat waves during the warm season (ONDJFM) expressed as percentage. Observations (black points), SMHI-RCA4 simulation (grey triangles) and their 31-day moving average (black line - observation, grey line - model simulation) are shown.

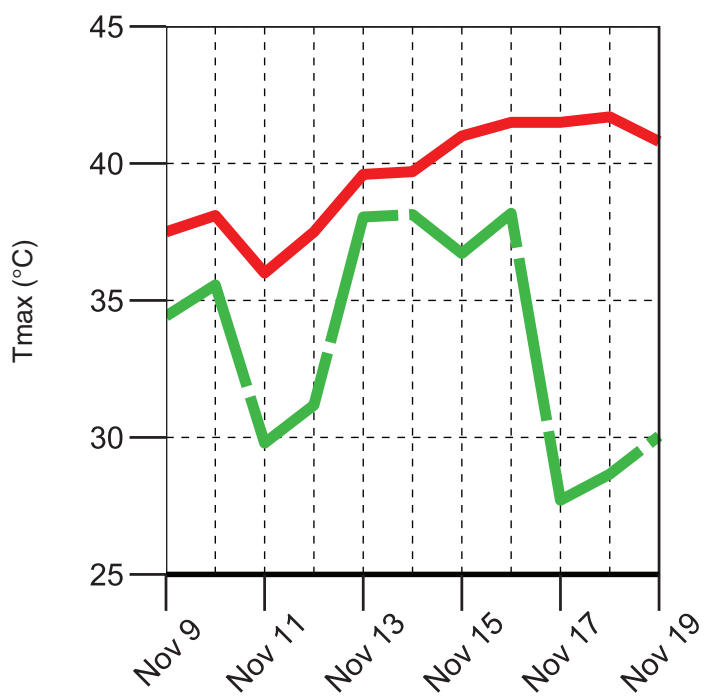

Figure 6. Daily maximum temperature $\left({ }^{\circ} \mathrm{C}\right.$ ) observed (solid line) and simulated (long dashed line) at Posadas station during the heat wave that occurred between November 9 and November 19, 1985. [Colour figure can be viewed at wileyonlinelibrary.com].

\subsection{Influence of ENSO on heat waves}

The ENSO is the main mode of climate variability in South America; therefore we analysed the influence of its phases on intensity, duration, and frequency of heat waves. The classification of warm seasons according to ENSO phases is shown in Table 4. There were 13 warm seasons with neutral conditions, 10 under El Niño conditions and 7 under La Niña conditions.

In the 1980-2010 period, we analysed how the parameters of heat waves are modified in the different ENSO phases and how the SMHI-RCA4 model reproduced these changes (Table 5). At five stations (Buenos Aires, Rosario, Mar del Plata, Resistencia and Santa Rosa), the most intense heat wave, identified in Section 3.2, occurred during the La Niña phase. In Cordoba and Posadas, the most intense heat wave took place in a neutral year, while the El Niño phase was linked to the most intense heat waves in the western part (Mendoza and Salta).

The accumulated TS90 index according to the ENSO phases showed a maximum in the La Niña phase in Buenos Aires, Cordoba, Rosario and Mar del Plata for observed data (Figure 8). We also found that during this ENSO phase the heat waves were longer, except in Mar del Plata (Figure S8). Furthermore, in Rosario and Cordoba the number of heat waves was higher during La Niña than in the other ENSO phases (Figure S9). In general, at these stations, the model overestimated the TS90 index in all ENSO phases (Table 5). In particular, the model substantially overestimated the TS90 index during La Niña events in Cordoba.

On the other hand, the western stations (Mendoza and Salta) exhibited the highest values of the TS90 index during El Niño conditions (Figures 3(d) and (h)). Salta 

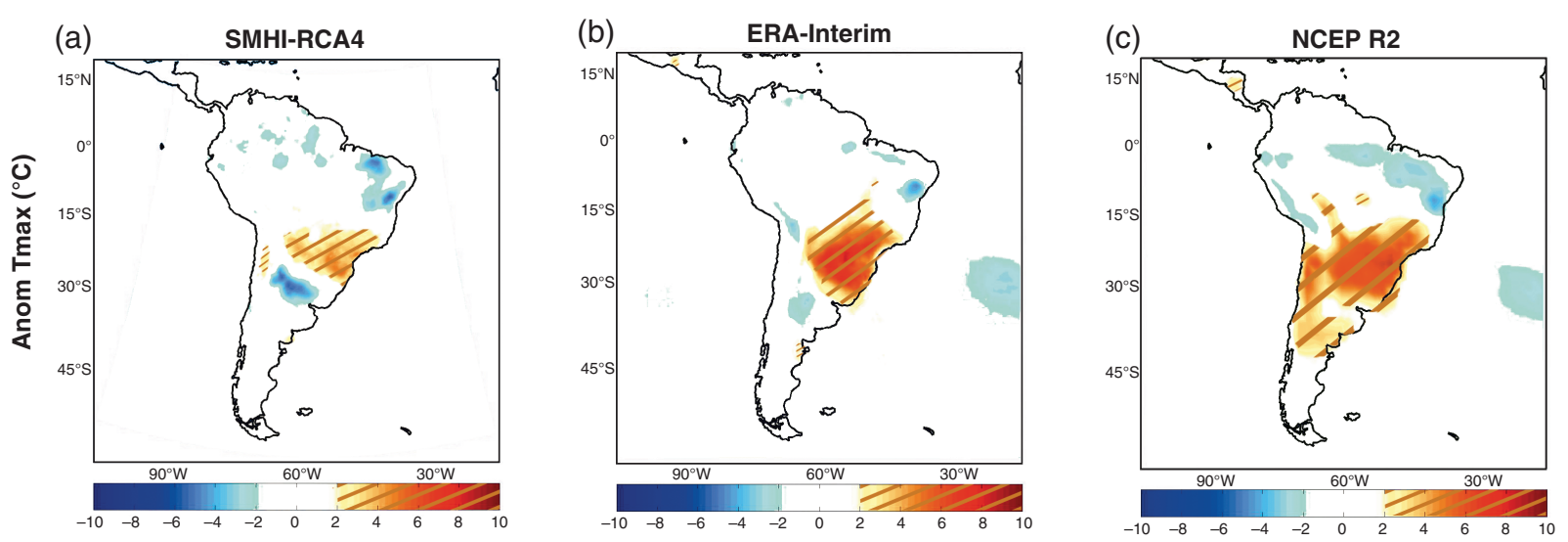

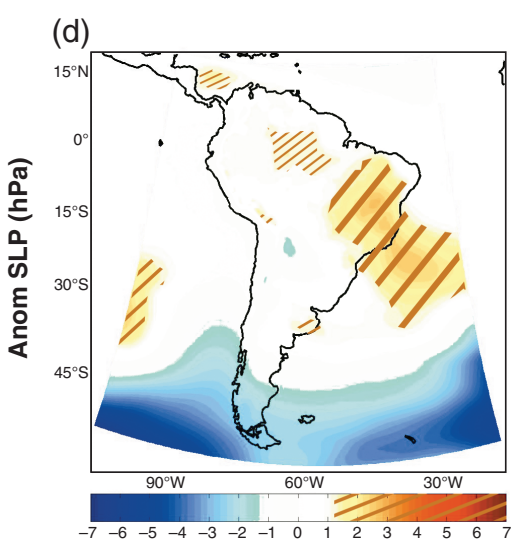

(e)

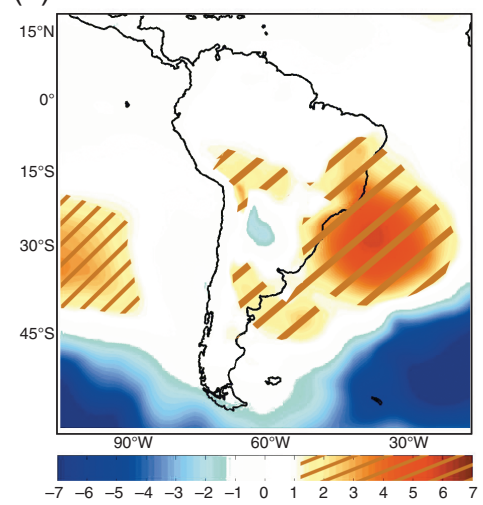

(h)

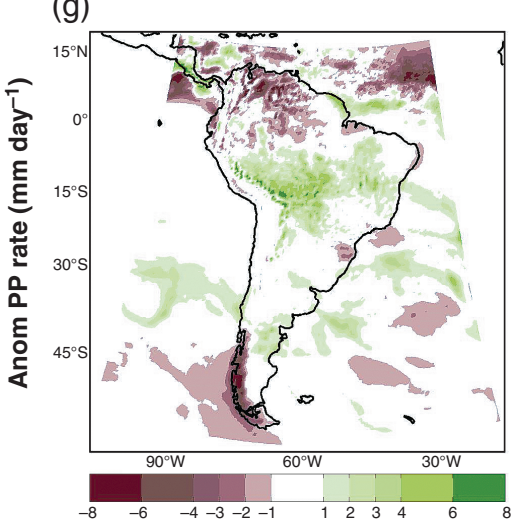

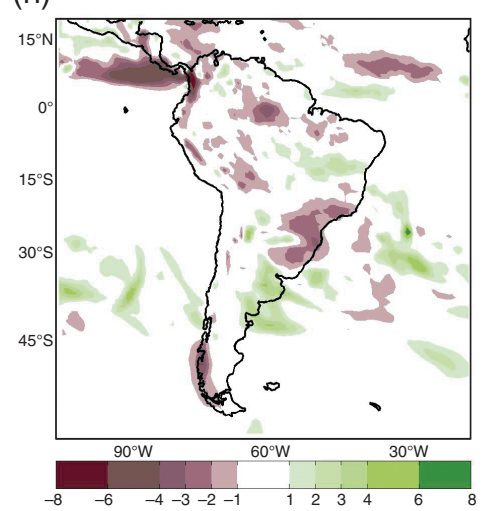

(f)

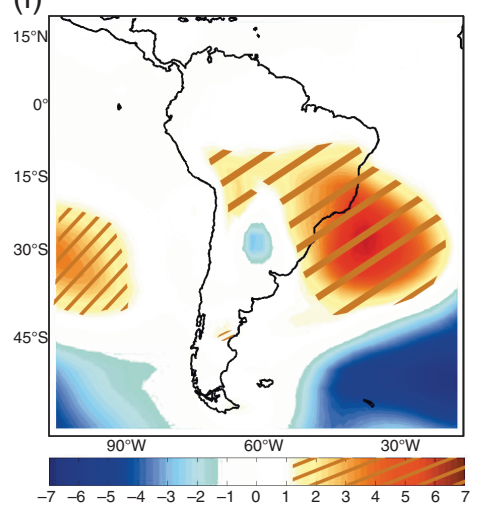

(i)

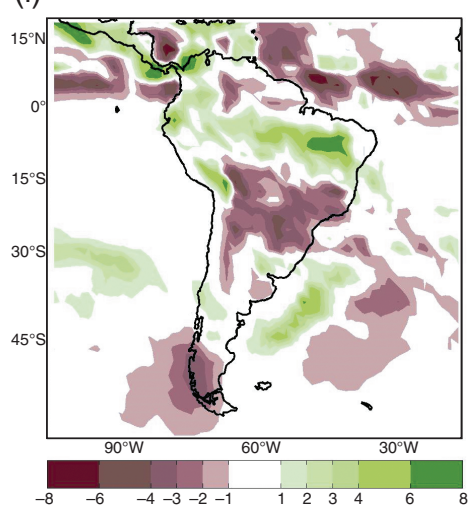

Figure 7. Daily maximum temperature anomalies $\left(\mathrm{a}, \mathrm{b}, \mathrm{c}{ }^{\circ} \mathrm{C}\right)$ and daily sea level pressure anomaly $(\mathrm{d}, \mathrm{e}, \mathrm{f}, \mathrm{hPa})$ from the mean November climatology (1981-2010) during the November 1985 heat wave in Posadas for the SMHI-RCA4 model, ERA-Interim and NCEP/DOE Reanalysis II, and daily precipitation rate anomalies $\left(\mathrm{g}, \mathrm{h}, \mathrm{i}, \mathrm{mm} \mathrm{day}^{-1}\right)$ in October 1985 with respect to the October climatology (1981-2010). [Colour figure can be viewed at wileyonlinelibrary.com].

showed increased frequency, duration and intensity of heat waves during the El Niño phase (Figures 8(h), S8, S9) but in Mendoza all the heat wave's parameters were similar between the phases. In Mendoza, the model overestimated the intensity, duration, and number of heat waves in both El Niño and La Niña phases while in Salta, an underestimation of the TS90 index during El Niño and La Niña phases and an overestimation during neutral years were found.

In the northeastern Argentina (Posadas and Resistencia), the highest value of the TS90 index occurred in the warm season of 1985-1986 during neutral condition. According to observations, in Posadas there were more heat waves that were longer and more intense in neutral years; however, the model simulated the most extreme heat waves during the La Niña phase (Figures 8(e) and (g), Figures S8 and S9). On the other hand, in Resistencia, the observed accumulated TS90 index was largest in neutral years, but heat waves were longer during the La Niña phase. The model showed a large overestimation of all parameters of heat waves during the La Niña phase at both locations, 
Table 4. Classification of warm seasons according to ENSO phases in the $1980-2010$ period.

\begin{tabular}{lcc}
\hline Neutral & El Niño & \multicolumn{1}{c}{ La Niña } \\
\hline $1980-1981,1981-1982$, & $1982-1983$, & $1984-1985$, \\
$1983-1984,1985-1986$, & $1986-1987$, & $1988-1989$, \\
$1989-1990,1990-1991$, & $1987-1988$, & $1995-1996$, \\
$1992-1993,1993-1994$, & $1991-1992$, & $1998-1999$, \\
$1996-1997,2001-2002$, & $1994-1995$, & $1999-2000$, \\
$2003-2004,2005-2006$, & $1997-1998$, & $2000-2001$, \\
$2008-2009$ & $2002-2003$, & $2007-2008$ \\
& $2004-2005$, & \\
& $2006-2007$, & \\
$\mathbf{1 3}$ events & $2009-2010$ & \\
\hline
\end{tabular}

while the simulation of these parameters was accurate during El Niño and neutral years. Finally, in Santa Rosa, the peak of the TS90 index in the 2003-2004 warm season (Figure 3(i)) occurred in a neutral year. However, there was not a large difference between phases in the accumulated TS90 index (Figure 8). The model overestimated the intensity of heat waves in all three phases, especially during the La Niña phase (Table 5). Despite the overestimation by the model, the ratio between the observed TS90 index and duration of heat waves was similar to that from model data for all locations, indicating that the proportion of overestimation in both parameters is comparable (Table 5).

\section{Discussion and summary}

The main objective of this study was to evaluate the capability of the SMHI-RCA4 model driven by the ERAInterim reanalysis to simulate heat waves over Argentina in the 1980-2010 period. This analysis was performed by comparing different parameters of heat waves estimated from nine meteorological stations with those calculated for the model. The gridded model data was interpolated to the position of the weather stations by applying the IDW method with the four nearest grid points.

The evaluation of the summer daily Tmax indicated the presence of warm biases at six of the nine locations analysed and an overestimation of its 90th percentile. In agreement with Tencer et al. (2016), two of the three cold Tmax biases were found in western Argentina (Salta and Mendoza), where the 90th percentile was also underestimated by the model. The other negative bias occurred in Posadas. The largest positive bias in LPB, particularly in Rosario, is in accordance with the findings by Solman et al. (2013) and Solman (2016) for summer mean temperature and López-Franca et al. (2016) for seasonal mean of maximum temperature. Carril et al. (2012) have already identified that the summer Tmax bias of a multi-RCM ensemble increases as analysis moves to the tails of the distributions in central Argentina. Possible causes of such systematic model errors may be deficiencies in representing land surface processes, which have a strong coupling

Table 5. Difference between the SMHI-RCA4 RCM and observation for each ENSO phase in: TS90 index, duration of heat waves and number of heat waves.

\begin{tabular}{|c|c|c|c|c|c|}
\hline & & TS90 index $\left({ }^{\circ} \mathrm{C}\right)$ & Duration (days) & Number of HW & TS90/duration \\
\hline & Neutral & 4.8 & 2.8 & 0.7 & -0.1 \\
\hline \multirow[t]{3}{*}{ Buenos Aires } & El Niño & 6.8 & 1.8 & 0.4 & 0.5 \\
\hline & La Niña & 1.9 & 0.1 & -0.3 & 0.2 \\
\hline & Neutral & -0.4 & 1.5 & 0.3 & -0.5 \\
\hline \multirow[t]{3}{*}{ Cordoba Obs } & El Niño & 2.9 & 2.6 & 0.3 & -0.5 \\
\hline & La Niña & 14.7 & 7.9 & 1.0 & -0.3 \\
\hline & Neutral & 0.2 & 2.1 & 0.5 & -0.5 \\
\hline \multirow[t]{3}{*}{ Rosario Aero } & El Niño & 1.9 & 1.8 & 0.3 & -0.3 \\
\hline & La Niña & 2.2 & -0.1 & -0.4 & 0.2 \\
\hline & Neutral & -0.4 & 0.2 & -0.2 & -0.2 \\
\hline \multirow[t]{3}{*}{ Mendoza Obs } & El Niño & 10.1 & 6.0 & 1.1 & -0.1 \\
\hline & La Niña & 6.4 & 4.7 & 1.1 & -0.3 \\
\hline & Neutral & 0.0 & 0.0 & -0.1 & 0.0 \\
\hline \multirow[t]{3}{*}{ Posadas Aero } & El Niño & 0.5 & 0.4 & -0.2 & 0.0 \\
\hline & La Niña & 22.2 & 8.9 & 1.7 & 1.0 \\
\hline & Neutral & 4.3 & 0.8 & 0.0 & 0.5 \\
\hline \multirow{3}{*}{ Mar del Plata Aero } & El Niño & 0.3 & -0.1 & -0.1 & 0.2 \\
\hline & La Niña & 0.0 & -1.3 & -0.3 & 0.7 \\
\hline & Neutral & -2.9 & 0.9 & 0.0 & -0.7 \\
\hline \multirow[t]{3}{*}{ Resistencia Aero } & El Niño & 1.0 & 0.8 & 0.2 & 0.0 \\
\hline & La Niña & 15.1 & 8.1 & 2.0 & 0.0 \\
\hline & Neutral & 2.3 & 2.6 & 0.8 & -0.4 \\
\hline \multirow[t]{3}{*}{ Salta Aero } & El Niño & -1.6 & 1.4 & -0.1 & -0.4 \\
\hline & La Niña & -0.2 & 0.7 & -0.1 & -0.3 \\
\hline & Neutral & 3.5 & 1.0 & 0.1 & 0.2 \\
\hline \multirow[t]{2}{*}{ Santa Rosa Aero } & El Niño & 0.1 & 0.0 & -0.5 & 0.0 \\
\hline & La Niña & 5.9 & 3.7 & 1.0 & -0.4 \\
\hline
\end{tabular}

These differences were divided by the number of seasons in each ENSO phase. In the last column, the difference between model and observations in the ratio between the TS90 index and duration is shown. 
(a)

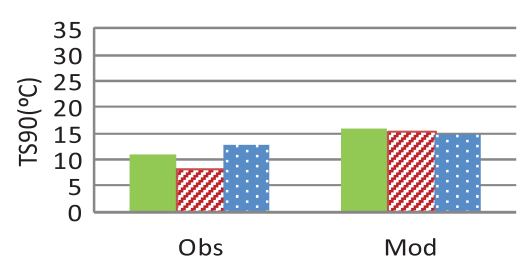

(d)

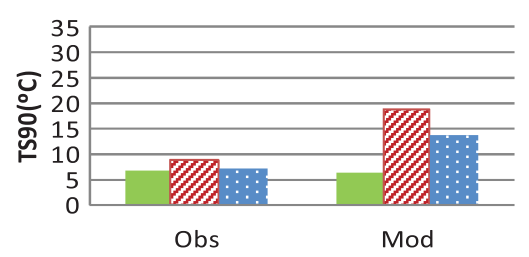

(g)

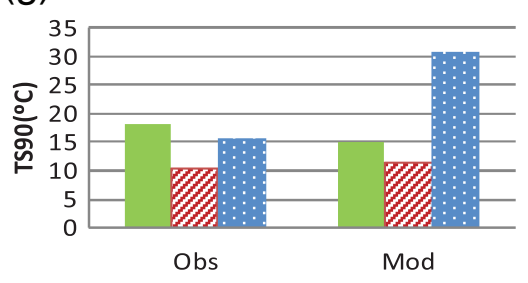

(b)

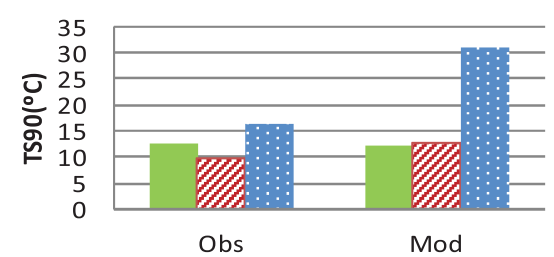

(e)

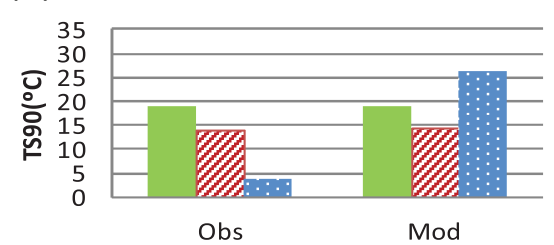

(h)

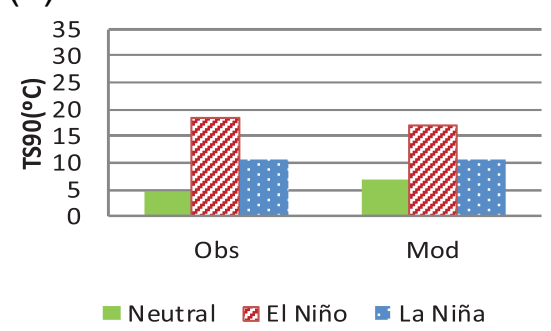

(c)

Rosario Aero

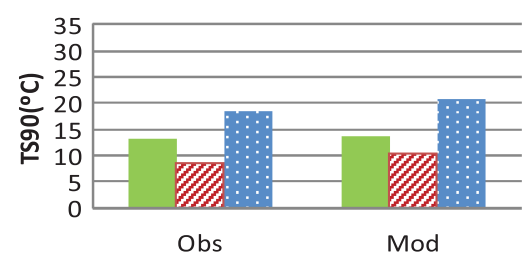

(f) Mar del Plata Aero

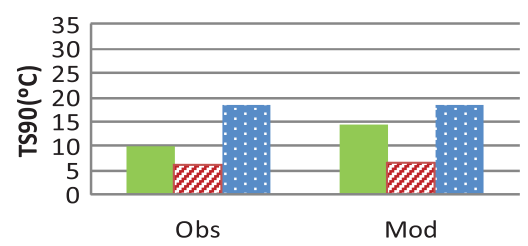

(i) Santa Rosa Aero

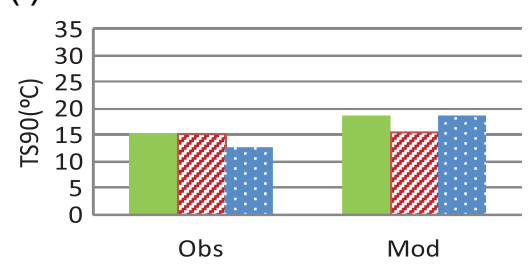

Figure 8. TS90 index $\left({ }^{\circ} \mathrm{C}\right.$ ) accumulated in each ENSO phase (solid - neutral, dashed - El Niño, dotted - La Niña), divided by the number of events in each phase for the observations and the model in the 1980-2010 period. [Colour figure can be viewed at wileyonlinelibrary.com].

with near-surface climate in this region, mainly during the warm season (Sörensson and Berbery, 2015). The biases in temperature and precipitation are not independent of each other (Carril et al., 2012), thus drier conditions may lead to overestimation in the near-surface temperature which in turn may amplify the negative precipitation bias due to positive feedback mechanisms. These results emphasize the need for RCM improvements to attain a better representation of the observed climate over the South American continent (Solman, 2016). Another possible reason for the model errors is the fact that the RCMs were originally developed for other regions of the world (Solman, 2013). Climate models, and especially RCA3, tend to overestimate maximum temperature in areas with a negative bias of precipitation (Carril et al., 2012). The drying out of the soil does not only depend on deficient rainfall, but also on the soil properties and physiographic factors affecting evapotranspiration and heat fluxes in the regional models such as roughness length, vegetation fraction, leaf area index, albedo, or rooting depth. Other possible factors that influence the daily Tmax over LPB, such as cloud cover and surface radiative forcing, were discussed by López-Franca et al. (2016). They showed that an ensemble of RCMs was able to capture the role of cloudiness in decreasing Tmax during the daytime by reflecting solar radiation. In addition, the local influence of the Paraná River at the Rosario station may not be represented correctly by the model due to its resolution.

The study of heat waves in the warm season showed an overestimation of the TS90 index, duration and number of heat waves by SMHI-RCA4 for all locations. However, the strongest heat waves tended to be underestimated by the model. In particular, we examined the intense heat wave that occurred in northeastern Argentina in November 1985 and found that one possible reason for the underestimation of Tmax was a weaker sea level pressure gradient simulated in the region, causing a reduced northerly advection of warm air masses. Previous studies had already emphasized the importance of northerly advection for the development of heat waves in this region (Rusticucci and Vargas, 1995; Campetella and Rusticucci, 1998; Alessandro and de Garín, 2003) and also found that RCMs simulated a too-weak northerly low-level jet in the subtropics (Wang and Fu, 2004; Carril et al., 2012). Another cause of this underestimation might be the simulation of moister soil conditions by the model in the previous month.

Another parameter analysed was the frequency of heat waves during the warm season. The model tends to considerably overestimate the frequency of heat waves from December to March at almost all locations analysed. The linear trends of the observed intensity and the number of days with heat waves in a warm season over the 1980-2010 period were not significant at the 5\% confidence level at any station, coinciding with the results of Perkins et al. (2012) for SESA in the 1950-2011 period.

The ENSO modulation of heat waves was not uniform among the locations. At stations located in the central part and southeast of the domain (Buenos Aires, Córdoba, Rosario and Mar del Plata) the highest values of the accumulated TS90 index occurred during La Niña phase. This 
might be due to the reduction of precipitation, which produces changes in sensible and latent heat fluxes between the soil and atmosphere (Ropelewski and Halpert, 1987; Vargas et al., 1999; Grimm et al., 2000).

The performance of the model in simulating heat waves in different phases of ENSO varies greatly according to the location analysed. At some stations, the parameters of heat waves are adequately represented in one of the ENSO phases, while in the other phases the performance is poor. In general, the overestimation predominated, e.g. in northeastern Argentina (Posadas and Resistencia) we found a great overestimation of the parameters in $\mathrm{La}$ Niña years and good results in the other phases. One possible reason for the differences between the model and observations in different ENSO phases might originate from the capability of the RCM to simulate different circulation patterns in each phase. On this matter, Solman (2013) assessed the capability of RCMs participating in CLARIS-LPB/CORDEX driven by ERA-Interim to simulate the interannual variability of rainfall in South America, and found that the RCMs systematically underestimate the rainfall amount in LPB, although they are capable of capturing the year-to-year variability in response to different forcings, such as ENSO. The underestimation of precipitation could be one of the causes of the overestimation of heat waves.

To sum up, the simulation of heat waves in the SMHI-RCA4 RCM exhibited substantial deficiencies over Argentina despite being driven by the ERA-Interim reanalysis and not by a GCM. An important limitation is the absence of long-term gridded observed temperature data in South America that would be useful for a comparison against RCM simulations. In future works, different RCMs could be evaluated in order to compare performance of other models with RCA4 and to present more robust findings based on a multimodel ensemble. This would also prepare a background for analysing future projections of heat waves in Argentina.

\section{Acknowledgements}

This research was supported by a joint project funded by the Ministerio de Ciencia, Tecnología e Innovación Productiva of Argentina (ARC/14/25) and the Ministry of Education, Youth and Sports of the Czech Republic (7AMB15AR001) (program MINCYT-MEYS). OL and JK were supported by the Czech Science Foundation, project 16-22000S. SC and MR were supported by CONICET PIP 0137-Res 4248/16. We want to thank the National Weather Service of Argentina for providing the data for this study.

\section{Supporting information}

The following supporting information is available as part of the online article:

Figure S1. Scatter plot of summer daily maximum temperature $\left({ }^{\circ} \mathrm{C}\right)$ between observed and model data averaged over the four nearest grid points, in the 1980-2010 period. The line indicates the "perfect model" (model equal to observations).

Figure S2. Total number of days with heat waves by warm season for observed data (bars) and model data (points) in the 1980-2010 period.

Figure S3. Number of heat waves by warm season for observed data (bars) and model data (points) in the 1980-2010 period.

Figure S4. Mean length of heat waves by warm season (total duration divided by the number of heat waves) for observed data (bars) and model data (points) in the 1980-2010 period.

Figure S5. Anomalies of monthly geopotential height at $1000 \mathrm{hPa}$ in November 1985 with respect to November climatology (1981-2010) from NCEP/NCAR Reanalysis I (a), NCEP/DOE Reanalysis II (b), ERA-Interim (c), and JRA-55 (d).

Figure S6. Monthly precipitation rate anomalies in October 1985 with respect to October climatology (1981-2010) from NCEP/NCAR Reanalysis I (a), NCEP/ DOE Reanalysis II (b), ERA-Interim (c), and JRA-55 (d). Figure S7. Total duration of heat waves per number of seasons in each ENSO phase for the observations and the model.

Figure S8. Number of heat waves per number of seasons in each ENSO phase for the observations and the model.

\section{References}

Alessandro AP, de Garín AB. 2003. A study on predictability of human physiological strain in Buenos Aires City. Meteorol. Appl. 10: 263-271. https://doi.org/10.1017/S1350482703003062.

Alvarez MS, Vera CS, Kiladis GN, Liebmann B. 2016. Influence of the Madden Julian Oscillation on precipitation and surface air temperature in South America. Clim. Dyn. 46: 245-262. https://doi.org/10.1007/ s00382-015-2581-6.

Anderson BG, Bell ML. 2009. Weather-related mortality: how heat, cold, and heat waves affect mortality in the United States. Epidemiology 20: 205-213. https://doi.org/10.1097/EDE.0b013e318190ee08.

Barriopedro D, Fischer EM, Luterbacher J, Trigo RM, Garcia-Herrera R. 2011. The hot summer of 2010: redrawing the temperature record map of Europe. Science 332: 220-224. https://doi.org/10.1126/science 1201224.

Beniston M, Stephenson DB, Christensen OB, Ferro CAT, Frei C, Goyette S, Halsnaes K, Holt T, Jylhä K, Koffi B, Palutikof J, Schöll R, Semmler T, Woth K. 2007. Future extreme events in European climate: an exploration of regional climate model projections. Clim. Change 81: 71-95. https://doi.org/10.1007/s10584-006-9226-z.

Campetella C, Rusticucci M. 1998. Synoptic analysis of an extreme heat wave over Argentina in March 1980. Meteorol. Appl. 5: 217-226. https://doi.org/10.1017/S1350482798000851.

Carril AF, Menéndez CG, Remedio ARC, Robledo F, Sörensson A, Tencer B, Boulanger JP, de Castro M, Jacob D, Le Treut H, Li LZX, Penalba O, Pfeifer S, Rusticucci M, Salio P, Samuelsson P, Sanchez E, Zaninelli P. 2012. Performance of a multi-RCM ensemble for south eastern South America. Clim. Dyn. 39: 2747-2768. https://doi.org/10 .1007/s00382-012-1573-z.

Carril AF, Cavalcanti IFA, Menéndez CG, Sörensson A, López-Franca N, Rivera JA, Robledo F, Zaninelli PG, Ambrizzi T, Penalba OC, da Rocha RP, Sánchez E, Bettolli ML, Pessacg N, Renom M, Ruscica R, Solman S, Tencer B, Grimm AM, Rusticucci M, Cherchi A, Tedeschi R, Zamboni L. 2016. Extreme events in the La Plata basin: a retrospective analysis of what we have learned during CLARIS-LPB project. Clim. Res. 68: 95-116. https://doi.org/10.3354/cr01374.

Cerne SB, Vera CS. 2011. Influence of the intraseasonal variability on heat waves in subtropical South America. Clim. Dyn. 36: 2265-2277. https://doi.org/10.1007/s00382-010-0812-4. 
De Bono A, Giuliani G, Kluser S, Peduzzi P. 2004. Impacts of summer 2003 heat wave in Europe. UNEP/DEWA/GRID-Europe. Environ. Alert Bull. 2: 1-4.

De Haan LL, Kanamitsu M. 2007. Increase in near-surface temperature simulation skill due to predictive soil moisture in a numerical seasonal simulation under observed SST forcing. J. Hydrometeorol. 9: 48-60. https://doi.org/10.1175/2007JHM796.1.

Dee DP, Uppala SM, Simmons AJ, Berrisford P, Poli P, Kobayashi S, Andrae U, Balmaseda MA, Balsamo G, Bauer P, Bechtold P, Beljaars ACM, van de Berg L, Bidlot J, Bormann N, Delsol C, Dragani R, Fuentes M, Geer AJ, Haimberger L, Healy SB, Hersbach H, Hólm EV, Isaksen L, Kållberg P, Köhler M, Matricardi M, McNally AP, Monge-Sanz BM, Morcrette J-J, Park B-K, Peubey C, de Rosnay P, Tavolato C, Thépaut J-N, Vitart F. 2011. The ERA-Interim reanalysis: configuration and performance of the data assimilation system. $Q$. J. Roy. Meteorol. Soc. 137: 553-597. https://doi.org/10.1002/qj.828.

Della-Marta PM, Luterbacher J, Weissenfluh H, Xoplaki E, Brunet M, Wanner H. 2007. Summer heat waves over western Europe 1880-2003, their relationship to large-scale forcings and predictability. Clim. Dyn. 29: 251-275. https://doi.org/10.1007/s00382-0070233-1.

Grimm AM, Barros VR, Doyle M. 2000. Climate variability in southern South America associated with El Niño and La Niña events. J. Clim. 13: $35-58$.

Kanamitsu M, Ebisuzaki W, Woollen J, Yang S, Hnilo JJ, Fiorino M, Potter GL. 2002. NCEP-DOE AMIP-II Reanalysis (R-2). Bull. Amer. Meteor. Soc. 83: 1631-1643. https://doi.org/10.1175/BAMS-83-111631.

Koster RD, Dirmeyer PA, Guo Z, Bonan G, Chan E, Cox P, Yamada T. 2004. Regions of strong coupling between soil moisture and precipitation. Science 305(5687): 1138-1140. https://doi.org/10.1126/science 1100217.

Kyselý J. 2010. Recent severe heat waves in central Europe: how to view them in a long-term prospect? Int. J. Climatol. 109: 89-109. https:// doi.org/10.1002/joc.1874.

Lhotka O, Kyselý J. 2015a. Spatial and temporal characteristics of heat waves over Central Europe in an ensemble of regional climate model simulations. Clim. Dyn. 45: 2351-2366. https://doi.org/10 .1007/s00382-015-2475-7.

Lhotka O, Kyselý J. 2015b. Characterizing joint effects of spatial extent, temperature magnitude and duration of heat waves and cold spells over Central Europe. Int. J. Climatol. 35: 1232-1244. https://doi.org/ $10.1002 /$ joc. 4050

Lhotka O, Kyselý J. 2015c. Hot central-European summer of 2013 in a long-term context. Int. J. Climatol. 35: 4399-4407. https://doi.org/10 $.1002 /$ joc. 4277 .

López-Franca N, Zaninelli PG, Carril AF, Menéndez CG, Sánchez E. 2016. Changes in temperature extremes for 21 st century scenarios over South America derived from a multi-model ensemble of regional climate models. Clim. Res. 68: 151-167. https://doi.org/10.3354/ cr01393.

Meehl G, Tebaldi C. 2004. More intense, more frequent, and longer lasting heat waves in the 21st century. Science 305: 994-997. https:// doi.org/10.1126/science. 1098704 .

Menéndez CG, Saulo AC, Li ZX. 2001. Simulation of south American wintertime climate with a nesting system. Clim. Dyn. 17: 219-231. https://doi.org/10.1007/s003820000107.

Menéndez CG, de Castro M, Boulanger JP, D’Onofrio A, Sanchez E, Sörensson AA, Blazquez J, Elizalde A, Jacob D, Le Truet H, Li ZX, Núñez MN, Pessacg N, Pfeiffer S, Rojas M. 2010. Downscaling extreme month-long anomalies in southern South America. Clim. Change 98: 379-403. https://doi.org/10.1007/s10584-009-9739-3.

Mueller B, Seneviratne SI. 2012. Hot days induced by precipitation deficits at the global scale. Proc. Natl. Acad. Sci. 109(31): 12398-12403. https://doi.org/10.1073/pnas.1204330109.

Nicolini M, Salio P, Katzfey JJ, McGregor JL, Saulo AC. 2002. January and July regional climate simulation over South America. J. Geophys. Res. 107(22): 1-13. https://doi.org/10.1029/2001JD000736.

Pearce JL, Hyer M, Hyndman RJ, Loughnan M, Dennekamp M, Nicholls N. 2016. Exploring the influence of short-term temperature patterns on temperature-related mortality: a case-study of Melbourne, Australia. Environ. Health 15: 107-117. https://doi.org/10.1186/s12940-0160193-1.

Perkins SE, Alexander LV. 2013. On the measurement of heat waves. J. Clim. 26: 4500-4517. https://doi.org/10.1175/JCLI-D-1200383.1 .

Perkins SE, Alexander LV, Nairn JR. 2012. Increasing frequency, intensity and duration of observed global heatwaves and warm spells. Geophys. Res. Lett. 39: L20714. https://doi.org/10.1029/2012GL053361.
Robine JM, Cheung SLK, Le Roy S, Van Oyen H, Griffiths C, Michel JP, Herrmann FR. 2008. Death toll exceeded 70,000 in Europe during the summer of 2003. C. R. Biol. 331: 171-178. https://doi.org/10.1016/j crvi.2007.12.001

Ropelewski CF, Halpert MS. 1987. Global and regional scale precipitation patterns associated with El Niño/Southern Oscillation. Mon. Weather Rev. 115: 2161-2165.

Rusticucci M. 2012. Observed and simulated variability of extreme temperature events over South America. Atmos. Res. 106: 1-17. https://doi.org/10.1016/j.atmosres.2011.11.001

Rusticucci M, Penalba OC. 2000. Interdecadal changes in the precipitation seasonal cycle over Southern South America and their relationship with surface temperature. Clim. Res. 16: 1-15.

Rusticucci M, Vargas W. 1995. Synoptic situations related to spells of extreme temperatures over Argentina. Meteorol. Appl. 2: 291-300.

Rusticucci M, Kyselý J, Almeira G, Lhotka O. 2016. Long-term variability of heat waves in Argentina and recurrence probability of the severe 2008 heat wave in Buenos Aires. Theor. Appl. Climatol. 124: 679-689. https://doi.org/10.1007/s00704-015-1445-7.

Rusticucci M, Barrucand M, Collazo S. 2017. Temperature extremes in the Argentina central region and their monthly relationship with the mean circulation and ENSO phases. Int. J. Climatol. 37: 3003-3017. https://doi.org/10.1002/joc.4895.

Samuelsson P, Jones CG, Willén U, Ullerstig A, Gollvik S, Hansson U, Jansson C, Kjellström E, Nikulin G, Wyser K. 2011. The Rossby Centre regional climate model RCA3: model description and performance. Tellus A 63: 4-23. https://doi.org/10.1111/j.1600-0870.2010 .00478.x

Seneviratne SI, Corti T, Davin EL, Hirschi M, Jaeger EB, Lehner I, Teuling AJ. 2011. Investigating soil moisture-climate interactions in a changing climate: a review. Earth Sci. Rev. 99(3): 125-161. https://doi.org/10.1016/j. earscirev.2010.02.004.

Skansi M, Brunet M, Sigró J, Aguilar E, Arevalo Groening JA, Bentancur OJ, Castellón Geier YR, Correa Amaya RL, Jácome H, Malheiros Ramos A, Oria Rojas C, Pasten AM, Sallons Mitro S, Villaroel Jiménez C, Martínez R, Alexander LV, Jones PD. 2013. Warming and wetting signals emerging from analysis of changes in climate extreme indices over South America. Global Planet. Change 100: 295-307. https://doi.org/10.1016/j.gloplacha.2012.11.004.

Solman SA. 2013. Regional climate modeling over South America: a review. Adv. Meteorol. 2013: 504357. https://doi.org/10.1155/2013/ 504357.

Solman SA. 2016. Systematic temperature and precipitation biases in the CLARIS-LPB ensemble simulations over South America and possible implications for climate projections. Clim. Res. 68: 117-136. https:// doi.org/10.3354/cr01362

Solman SA, Sanchez E, Samuelsson P, da Rocha R, Li L, Marengo J, Pessacg NL, Remedio ARC, Chou SC, berbery H, Le Treut H, de Castro M, Jacob D. 2013. Evaluation of an ensemble of regional climate model simulations over South America driven by the ERAInterim reanalysis: models' performance and uncertainties. Clim. Dyn. 41: 1139-1157. https://doi.org/10.1007/s00382-013-1667-2.

Sörensson A, Berbery EH. 2015. A note on soil moisture memory and interactions with surface climate for different vegetation types in $\mathrm{La}$ Plata basin. J. Hydrometeorol. 16: 716-729. https://doi.org/10.1175/ JHM-D-14-0102.1.

Sörensson AA, Menéndez CG. 2011. Summer soil-precipitation coupling in South America. Tellus 63A: 56-68. https://doi.org/10.1111/j 1600-0870.2010.00468.x

Tencer B, Rusticucci M, Jones P, Lister D. 2011. A southeastern South American daily gridded dataset of observed surface minimum and maximum temperature for 1961-2000. Bull. Am. Meteorol. Soc. 92: 1339-1346. https://doi.org/10.1175/2011BAMS3148.1.

Tencer B, Bettolli ML, Rusticucci M. 2016. Compound temperature and precipitation extreme events in southern South America: associated atmospheric circulation, and simulations by a multi-RCM ensemble. Clim. Res. 68: 183-199. https://doi.org/10.3354/cr01396.

Urrutia R, Vuille M. 2009. Climate change projections for the tropical Andes using a regional climate model: temperature and precipitation simulations for the end of the 21st century. J. Geophys. Res. 114: D02108. https://doi.org/10.1029/2008JD011021.

Vargas W, Penalba O, Minetti J. 1999. Las precipitaciones mensuales en zonas de la Argentina y el ENOS. Un enfoque hacia problemas de decisión. Meteorológica 24: 3-22.

Wang H, Fu R. 2004. Influence of cross-Andes flow on the South American low-level jet. J. Clim. 17: 1247-1262. https://doi.org/10 .1175/1520-7200442(2004)017\&lt;1247:IOCFOT\&gt;2.0.CO;2. 